\title{
Winter marine atmospheric conditions over the Japan Sea
}

\author{
C. E. Dorman, ${ }^{1}$ R. C. Beardsley, ${ }^{2}$ N. A. Dashko, ${ }^{3,4}$ C. A. Friehe, ${ }^{5}$ D. Kheilf, ${ }^{5}$ \\ K. Cho, ${ }^{6}$ R. Limeburner, ${ }^{2}$ and S. M. Varlamov ${ }^{3,4}$ \\ Received 30 October 2001; revised 9 August 2004; accepted 3 September 2004; published 8 December 2004.
}

[1] Four basic types of synoptic-scale conditions describe the atmospheric structure and variability observed over the Japan Sea during the 1999/2000 winter season: (1) flow of cold Asian air from the northwest, (2) an outbreak of very cold Siberian air from the north and northeast, (3) passage of a weak cyclone over the southern Japan Sea with a cold air outbreak on the backside of the low, and (4) passage of a moderate cyclone along the northwestern side of the Japan Sea. In winter, the Russian coastal mountains and a surface-air temperature inversion typically block cold surface continental air from the Japan Sea. Instead, the adiabatic warming of coastal mountain lee-side air results in small air-sea temperature differences. Occasional outbreaks of very cold Siberian air eliminate the continental surface-based inversion and stability, allowing very cold air to push out over the Japan Sea for 1-3 days. During these outbreaks, the $0^{\circ} \mathrm{C}$ surface air isotherm extends well southward of $40^{\circ} \mathrm{N}$, the surface heat losses in the center of the Japan Sea can exceed $600 \mathrm{~W} \mathrm{~m}^{-2}$, and sheet clouds cover most of the Japan Sea, with individual roll clouds extending from near the Russian coast to Honshu. During December through February, 1991-2002, these strong cold-air outbreak conditions occur $39 \%$ of the time and contribute $43 \%$ of the net heat loss from the Japan Sea. The average number of strong cold-air events per winter (November-March) season is 13 (ranging from 5 to 19); the 1999/2000 winter season covered in our measurements was normal. INDEX TERMS: 4247 Oceanography: General: Marine meteorology; 4504 Oceanography: Physical: Air/sea interactions (0312); 3307 Meteorology and Atmospheric Dynamics: Boundary layer processes; 3329 Meteorology and Atmospheric Dynamics: Mesoscale meteorology; KEYWORDS: marine meteorology, air/sea interaction, Japan Sea

Citation: Dorman, C. E., R. C. Beardsley, N. A. Dashko, C. A. Friehe, D. Kheilf, K. Cho, R. Limeburner, and S. M. Varlamov (2004), Winter marine atmospheric conditions over the Japan Sea, J. Geophys. Res., 109, C12011, doi:10.1029/2001JC001197.

\section{Introduction}

[2] The Japan Sea is a marginal sea sandwiched between contrasting extremes. Climatically, it is situated between one of the world's most extensive, coldest continental anticyclones and one of the existing high-volume, warm western ocean boundary currents. Geographically, it is between the world's largest continent and largest ocean. Understanding the area's unique meteorological conditions, which include air-sea interaction complicated by the mountainous topography (Figure 1), has proven challenging.

\footnotetext{
${ }^{1}$ Center for Coastal Studies, Scripps Institution of Oceanography, University of California, San Diego, La Jolla, California, USA.

${ }^{2}$ Department of Physical Oceanography, Woods Hole Oceanographic Institution, Woods Hole, Massachusetts, USA.

${ }^{3}$ Dynamics Simulation Research Center, Research Institute for Applied Mechanics, Kyushu University, Kasuga, Japan.

${ }^{4}$ Permanently at Far Eastern State Technical Fisheries University, Vladivostok, Russia.

${ }^{5}$ Department of Mechanical and Aerospace Engineering, University of California, Irvine, California, USA.

${ }^{6}$ Research and Information Center, Tokai University, Tokyo, Japan.

Copyright 2004 by the American Geophysical Union. 0148-0227/04/2001JC001197\$09.00
}

Especially interesting are the winter conditions when cold Asian air moves out over the relatively warm sea, extracting large amounts of heat. The extent of the winter heat loss during cold air outbreaks was first noted in the pioneering work of Manabe [1957, 1958] and later expanded upon in more recent studies [Kato and Asai, 1983; Na et al., 1992, 1999; Hirose et al., 1996; Kawamura and Wu, 1998]. However, to our knowledge, no comprehensive in situ surface measurements have been collected over the Japan Sea to quantify the surface forcing.

[3] In the winter of 1999-2000, an international program involving Russian, Korean, Japanese, and American scientists took place to investigate the oceanography of the Japan Sea and its surface forcing. During this program, special atmospheric measurements were made, including ship and aircraft observations, to understand the nature of the lower atmosphere and surface momentum and heat fluxes. Here we examine the nature of wintertime conditions over the Japan Sea based on these new 1999-2000 measurements as well as some historical data. In particular, we found that winter can be characterized by four basic types of synopticscale conditions: (1) the dominant flow of cold Asian air toward the southeast over the Japan Sea, (2) occasional very cold Siberian air outbreaks from the north and northeast, (3) 

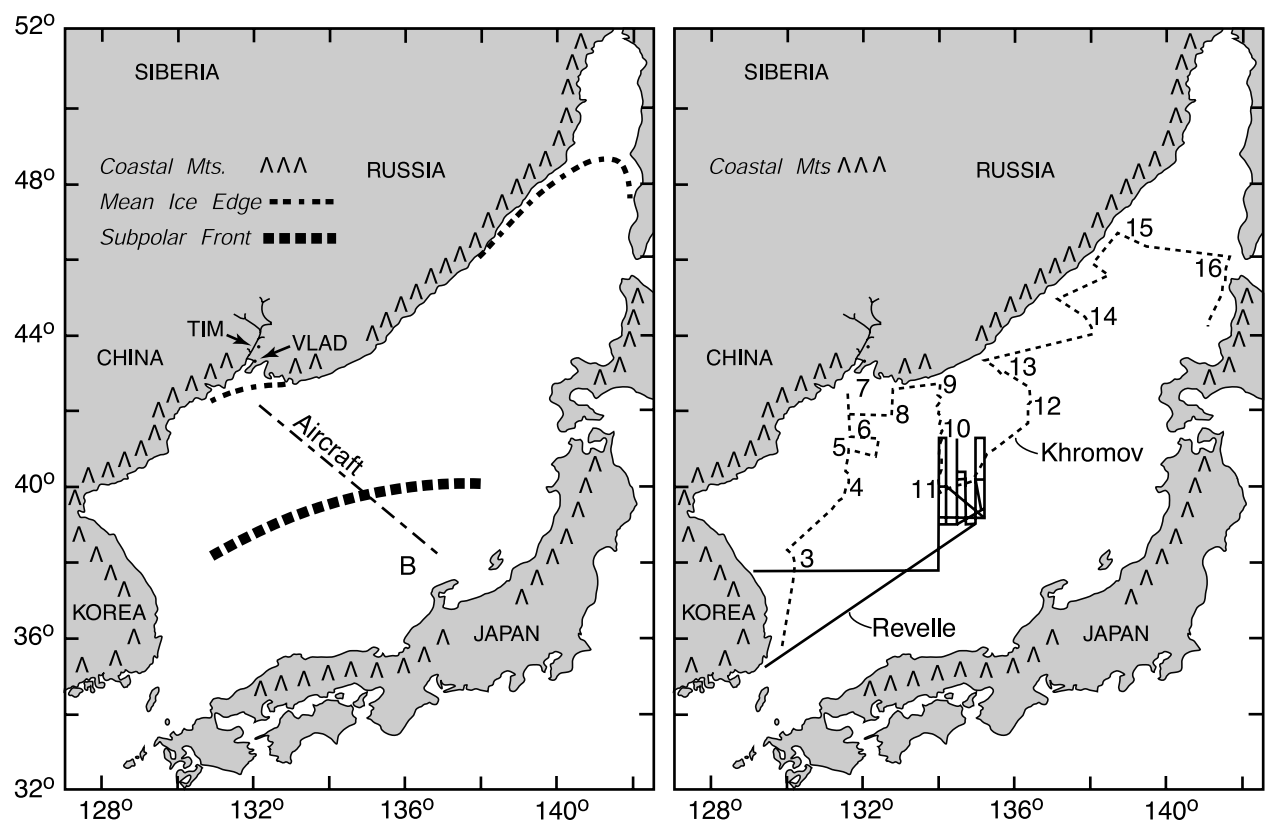

Figure 1. Japan Sea and surrounding land, showing the areas covered by the 1999-2000 winter measurements, the coastal topography, and key weather stations. VLAD, Vladivostok automated surface station and operational sounding station (Sad-Gorod); B, Japanese Meteorological Agency buoy 21002; TIM, Timiryazevsky surface station; Revelle, R/V Revelle track 4-17 January 2000; Aircraft (light dashed line, left frame), aircraft track on 3 February 2000; and Khromov (light dashed line, right frame), R/V Khromov track 3-16 February 2000. The thick dotted line (left panel) is the sea ice mean edge during January [from Yakunin, 1999]. The thick curved dashed line (left panel) is the mean position of the subpolar front during the same time period. The thin line leading northeast from Vladivostok shows the Razdol'naya River valley.

passage of a weak cyclone over the southern Japan Sea with a cold air outbreak on the backside of the low, and (4) passage of a moderate cyclone along the northwestern side of the Japan Sea.

[4] This paper is organized as follows. After a brief description of the data sets used in this study (section 2), the winter climatology and mean surface conditions are presented (section 3), followed by a description of the 1999/ 2000 winter conditions based on the in situ measurements (section 4). Then more detailed descriptions of the four basic synoptic conditions are presented (section 5). The ship-based estimates of the surface momentum and heat fluxes are presented next (section 6) and compared with flux estimates produced by the ECMWF model. Composites of the ECMWF fields are used to describe the surface air-sea flux patterns associated with the mean and very cold Siberian air outbreaks (section 7). Discussion and summary are presented in sections 8 and 9 .

\section{Measurements}

[5] The 1999/2000 winter field program collected atmospheric data over the Japan Sea using coastal surface and upper air stations, two research vessels, a meteorological buoy, and a research aircraft. A summary of the different measurements and data sets used in this study are shown in Table 1.

[6] The coastal station at Vladivostok, the Scripps Institution of Oceanography (SIO) research vessel Roger Revelle, and the Japanese Meteorological Agency Buoy
21002 form a rough transect that runs approximately perpendicular to the long axis and across the center of the Japan Sea (Figure 1). The northern station is in Vladivostok, where an SIO automated meteorological station was mounted at $49 \mathrm{~m}$ above sea level on the roof of the eightstory Far Eastern Regional Hydrometeorological Research Institute (FERHRI) headquarters building. This station is located within roughly $1 \mathrm{~km}$ of Amursky Bay, into which the Razdol'naya River flows. Measurements of wind speed, direction, air temperature, humidity, pressure, and solar insolation were averaged over 10-min intervals and recorded.

[7] The second station in this transect was the R/V Roger Revelle. The Roger Revelle was located mostly in the central portion of the Japan Sea within the area bounded by $36^{\circ} \mathrm{N}-$ $41^{\circ} \mathrm{N}, 133^{\circ} \mathrm{E}-136^{\circ} \mathrm{E}$ between 17 January and 4 February 2000 . Winds were measured at 1 -s intervals by an anemometer mounted on a bow mast $16.8 \mathrm{~m}$ above the sea. These relative winds were later corrected for the ship's motion using GPS and the ship's gyro data. Other sensors were mounted on the ship to measure air temperature, humidity, pressure, sea temperature, incident short-wave radiation, and incident long-wave radiation. These measurements were later used to make bulk estimates of the surface wind stress and heat flux following Beardsley et al. [1998], Pawlowicz et al. [2001], Bradley et al. [2000], and Fairall et al. [2003].

[8] The third station was the Japanese Meteorological Agency (JMA) automated meteorological buoy 21002 anchored in the south central portion of the Japan Sea at $37.92^{\circ} \mathrm{N}, 134.55^{\circ} \mathrm{E}$. Spot values of the winds, air tempera- 
Table 1. Summary of Variables Measured and Data Sources ${ }^{\mathrm{a}}$

\begin{tabular}{|c|c|}
\hline Data Sources and Variables & Principal Investigators \\
\hline \multicolumn{2}{|l|}{ 1. SIO/FERHRI Station FERHRI } \\
\hline Surface WIND, AT, RH, BP, SW & Dorman, Varlamov, Volkov \\
\hline \multicolumn{2}{|l|}{ 2. $\mathrm{R} / \mathrm{V}$ Revelle } \\
\hline Surface WIND, AT, RH, BP, SW, LW, SST & Limeburner, Beardsley, Dorman \\
\hline Profile WIND, AT, RH, BP & Dorman \\
\hline \multicolumn{2}{|l|}{ 3. JMA buoy 21002} \\
\hline Surface WIND, AT, RH, BP, SST & Dorman, Varlamov \\
\hline \multicolumn{2}{|l|}{ 4. R/V Khromov } \\
\hline Surface WIND, AT, RH, BP, SW, LW, SST & Limeburner, Beardsley \\
\hline \multicolumn{2}{|l|}{ 5. Sad-Gorod Station } \\
\hline Profile WIND, AT, RH, BP & Dorman, Dashko \\
\hline \multicolumn{2}{|l|}{ 6. CIRPAS Twin Otter } \\
\hline \multicolumn{2}{|l|}{ 7. Stationary Satellite } \\
\hline Visual and IR & Cho, Matsumoto \\
\hline \multicolumn{2}{|l|}{ 8. JMA Analysis } \\
\hline Surface AT, BP, SST; 850, 700, $500 \mathrm{Ht}$, AT & Varlamov \\
\hline \multicolumn{2}{|l|}{ 9. Timiryazevsky Station } \\
\hline Surface WIND, AT, BP & Uraevsky \\
\hline \multicolumn{2}{|l|}{ 10. ECMWF Analysis } \\
\hline Surface WIND, Net HEAT FLUX & Varlamov \\
\hline
\end{tabular}

${ }^{a}$ Wind Speed and Direction (WIND); Air Temperature (AT); Relative Humidity (RH); Barometric Pressure (BP); Incident Shortwave Radiation (SW); Incident Long-Wave Radiation (LW); Sea-Surface Temperature (SST); Wind Stress (WIND STRESS); Sensible and Latent Heat Fluxes (Air-Sea HEAT FLUX); Net Heat Flux (Net HEAT FLUX); and Altitude in hPa (Ht).

ture, dew point, sea surface temperature, and pressure were sent to the JMA by radio every 3 hours.

[9] Other surface measurements were made on the FERHRI R/V Professor Khromov during a late winter cruise in the Japan Sea on 2-15 March 2000. This cruise began from Korea and went first to the area off Vladivostok, then along the Russian coast before crossing the northern end of the Japan Sea to Japan. In addition to the ship's standard meteorological instrumentation, the ship was equipped for this cruise with portable instruments to measure wind, air temperature, relative humidity, pressure, incident shortwave radiation, incident long-wave radiation, and sea surface temperature [Hosom and Weller, 2001]. Surface wind stress and heat fluxes were estimated for this cruise following the same methods applied to the Roger Revelle data.

[10] Data from two upper-air sounding stations were especially important to this investigation. One was the Russian Sad-Gorod RAWIND sounding station UHXX at $43.27^{\circ} \mathrm{N}, 132.05^{\circ} \mathrm{E}$, where balloon sounding measurements of wind, air temperature, humidity, and pressure were made from the station elevation at $82 \mathrm{~m}$ to 500 mbar every 12 hours. This station is located on the outskirts of Vladivostok, approximately $26 \mathrm{~km}$ north of the SIO/FERHRI surface station and 1-2 km from the coast of Amursky Bay. Two soundings a day were also made from the Roger Revelle using a Vaisala-Marwin system with GPS sondes.

[11] Marine boundary layer measurements were also made during February 2000 using a research aircraft supplied by the Center for Interdisciplinary Remotely Piloted Aircraft Studies (CIRPAS). The Twin Otter aircraft, based in northern Japan, made a series of low-level and vertical profile flights across the Japan Sea to near Vladivostok and back. The object of these aircraft flights was to measure the structure of the marine boundary layer and turbulent fluxes with a special focus on the subpolar sea surface temperature frontal region.

[12] The results of analysis of historical surface weather and heat flux data produced by European Centre for
Medium-Range Weather Forecasts (ECMWF) [1995] were also used in this study. This work is described in section 8 . In an examination of oceanic surface conditions similar to the Japan Sea, Renfrew et al. [2002] and Moore and Renfrew [2002] found that the ECMWF and NCEP/NCAR reanalysis results correspond reasonably well with surface variables and fluxes measured or estimated using high-quality shipboard observations. This conclusion is supported by comparisons of our Roger Revelle winter observations with ECMWF values over the Japan Sea (C. E. Dorman et al., Summer atmospheric conditions over the Japan/East Sea, submitted to Deep Sea Res. II Special Japan Sea Issue, 2004) (hereinafter referred to as Dorman et al., submitted manuscript, 2004); for example, the ECMWF net heat flux had a 0.8 correlation with the ship-based flux. A similar result is given by Renfrew et al. [2002], who found that the differences between ECMWF latent and sensible heat fluxes and ship-based fluxes over the Labrador Sea were within measurement uncertainty. These results give confidence in the results of the analysis of ECMWF and NCEP/NCAR surface fields presented in this study.

\section{A Mean January}

[13] The winter climatology over the Japan Sea has been placed in the context of the winter East Asian monsoon [Boyle and Chen, 1987]. The January 2000 mean sea level pressure (from the NCEP/NCAR Reanalysis Project at the NOAA-CIRES Climate Diagnostics Center, Figure 2) illustrates the two dominant large-scale winter features, the Siberian Anticyclone (High) centered near $100^{\circ} \mathrm{E}$, $50^{\circ} \mathrm{N}$, and the Aleutian Cyclone (Low) in the Gulf of Alaska, which result in nominally meridional isobars over the Japan Sea. At $500 \mathrm{hPa}$, a broad trough is generally centered over the latitude of eastern Japan [Crutcher and Meserve, 1970] and is a portion of the largest amplitude stationary wave on the globe [Wallace, 1983]. This mean condition is modified by alternating traveling cyclones and 


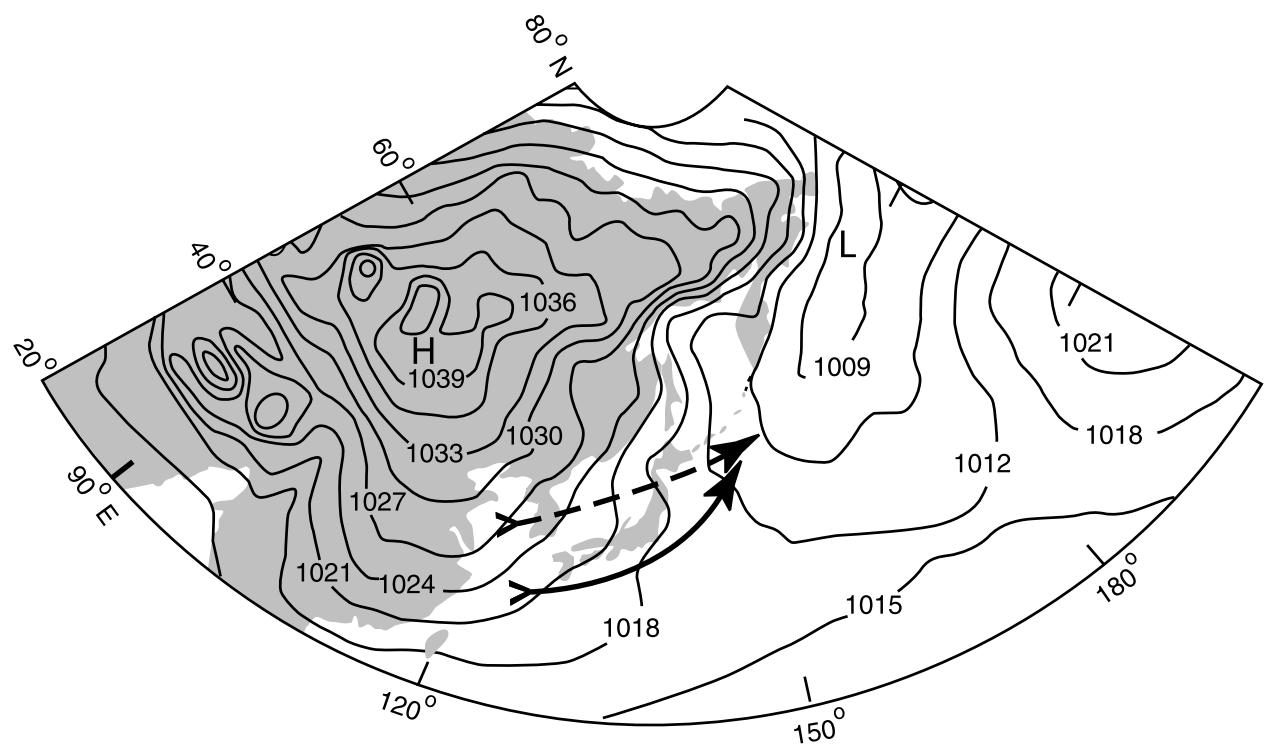

Figure 2. Large-scale view of the January 2000 sea level pressure field, showing the locations of the Siberian High $(\mathrm{H})$, the Aleutian Low (L), and the main track (solid arrow) and secondary track (dashed arrow) of low-pressure systems relative to the Japan Sea. The pressure field is adapted from that produced by the NCEP/NCAR Reanalysis Project at the NOAA-CIRES Climate Diagnostics Center.

anticyclones that Ramage [1971] suggested would exclude this area as part of a true monsoon system, although the distinction is not important for us. In any event, winter cyclones are generated primarily to the southwest, south, and east of Japan; they then move to the east-northeast [Whittaker and Horn, 1982]. Most fronts tend to form over the East China Sea and move to the northeast along the south side of Japan. Less frequently, fronts can form in the East China Sea and move through the Tsushima Strait over the relatively warm Tsushima Current [Yeh and Chen, 1984].

[14] The mean winter condition is that cold air moving over the eastern Asian continent then moves over the Japan Sea. The result is that the mean winter surface winds over the central Japan Sea are from the northwest. Dashko et al. [1997] found in an analysis of January Japan Sea ship measured winds that in the central portion of the Japan Sea, $36-40 \%$ of the winds were from the northwest, $18-20 \%$ from the west, $16 \%$ from the north, and $8 \%$ were from the northeast. See Dashko and Varlamov [1997, 2000] for further details of the Japan Sea winter climatological winds.

[15] The JMA January 2000 mean analyses are used here to further illustrate the typical winter conditions over the Japan Sea (Figure 3). The mean surface pressure features meridional isobars over the center of the sea, the Siberian High to the northwest, and the Aleutian Low to the east. At $850 \mathrm{hPa}$, the trend has shifted to the lowest pressures being in the northeast and the highest in the southwest portion of the analysis domain. At $500 \mathrm{hPa}$, the isoheights are zonal over the Japan Sea, with a low off to the northeast. The air temperature at this level is also zonally oriented, with a stronger gradient over the Japan Sea as compared to that over Russia.

[16] The coldest sea surface temperatures, near $0^{\circ} \mathrm{C}$, are found along the Russian central and southern coast, including near Vladivostok (Figure 4). Although not apparent here due to the northern limitation of the JMA SST analysis, the $0^{\circ} \mathrm{C}$ isotherm should have included the extreme northeast portion of the Japan Sea above $47^{\circ} \mathrm{N}$, which is generally icecovered in winter, especially in the shallow water to the west of Sakhalin Island. Ice is also found in the immediate vicinity of Vladivostok [Martin et al., 1992; Yakunin, 1999]. For the rest of the Japan Sea, the sea surface temperature increased to the south, reaching a maximum in the Tsushima Strait.

[17] The January mean surface-air temperatures are -20 to $-15^{\circ} \mathrm{C}$ inland and to the west, rising to $-0^{\circ} \mathrm{C}$ along the Russian coast (Figure 3). The large surface-air temperature gradient across the Russian coast suggests significant coastal mountain lee-side warming, since the dominant airflow direction is almost exclusively offshore and thus not due to northward advection of warmer marine air. Over the sea, surface-air temperature isotherms tend to be oriented southwest-northeast, increasing from the Russian coast to near the Japanese coast when moving from north to south over the center of the sea. However, this trend is interrupted close to Japan. The relatively warm Tsushima Current entering the Tsushima Strait has a significant affect, forcing the warmest air to be in the southwestern corner of the Japan Sea. The $0^{\circ} \mathrm{C}$ isotherm location, used as an operational index of the severity of cold air advection, is generally zonally oriented and north of the center of the Japan Sea.

[18] The coldest and driest air moves over the Japan Sea as episodic, cold air outbreaks, occurring infrequently. These very cold air outbreaks are air formed in the Siberian High where January mean surface-air temperatures could be $-50^{\circ} \mathrm{C}$ and January mean daily minimum surface-air temperatures are near -60 to $-70^{\circ} \mathrm{C}$ (the Siberian High air mass has the lowest surface-air temperatures experienced by nonglaciated, continental expanses). Cold air movement from the interior to the Japan Sea is blocked to a degree by coastal topography along the Russian coast (1-2 km 



Figure 3. JMA January 2000 mean analysis fields: sea level pressure, surface air temperature, $850-\mathrm{hPa}$ height, $850-\mathrm{hPa}$ air temperature, 500-hPa height, and 500-hPa air temperature.

high) and along the North Korean coast (2-2.8 km high) (Figure 1). Strategically placed cyclonic events broadly advect air to the Japan Sea over the Russian coastal mountains and as an intensified stream down the river valley headed by Vladivostok.

[19] The typical 0000 UTC January 2000 Sad-Gorod sounding has a surface-based inversion capped by an isothermal layer extending above $850 \mathrm{hPa}$ (not shown). This isothermal layer is well established inland as shown by the mean $850-\mathrm{hPa}$ temperatures over Russia being similar to the underlying surface-air temperature (Figure 3). This is caused by the cooling of the Asian air mass from the bottom as it travels over the interior continental area. The high stability of the surface-air temperature inversion prevents strong momentum at $950-850 \mathrm{hPa}$ from penetrating to the ground, so that the Vladivostok surface winds are usually weak. The weakness of the surface winds over eastern Russia in January 2000 was confirmed by the Timiryazevsky surface station (not shown), located some $120 \mathrm{~km}$ to the north of Vladivostok (Figure 1). The strongest winds at Timiryazevsky were about $6 \mathrm{~m} \mathrm{~s}^{-1}$, with most less than $3 \mathrm{~m} \mathrm{~s}^{-1}$. The air temperatures there were down to -20 to $-35^{\circ} \mathrm{C}$ at sunrise.

[20] During strong cold air outbreaks, lee-side warming effects and expansion tends to suppress clouds in the immediate vicinity of the Russian coast. Forced convection rolls aligned with the surface wind form in a deepening marine layer that appears in satellite images within tens of kilometers of the Russian coast, and individual rolls often extend across to Japan [Fett, 1979]. Nagata et al. [1986]

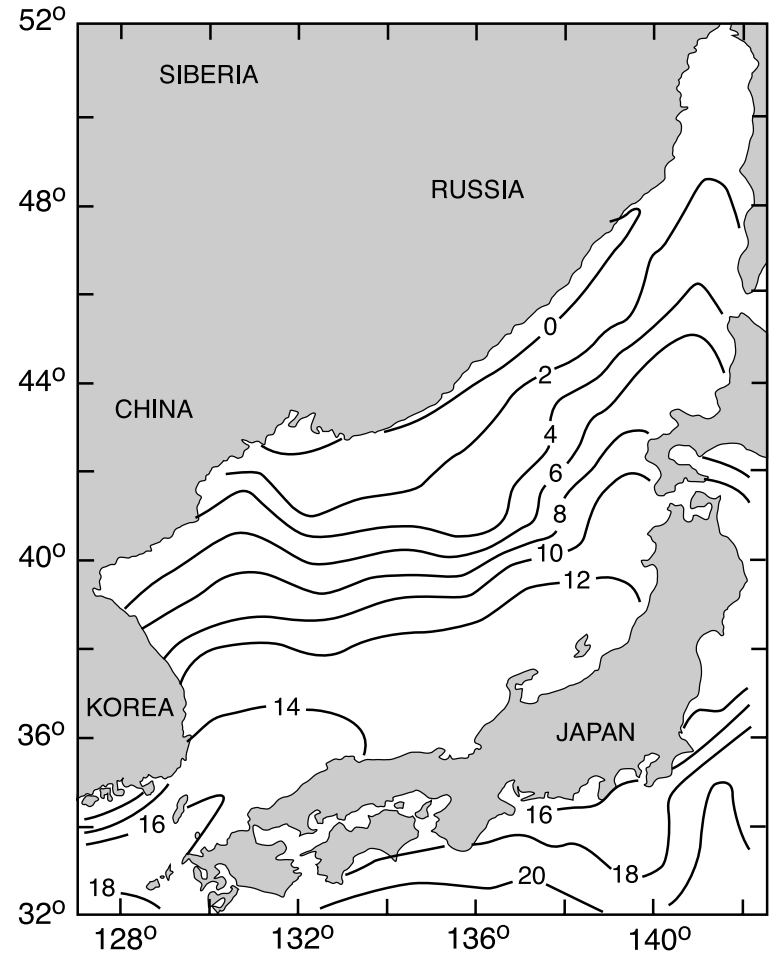

Figure 4. JMA January 2000 mean sea surface temperature $\left({ }^{\circ} \mathrm{C}\right)$. 

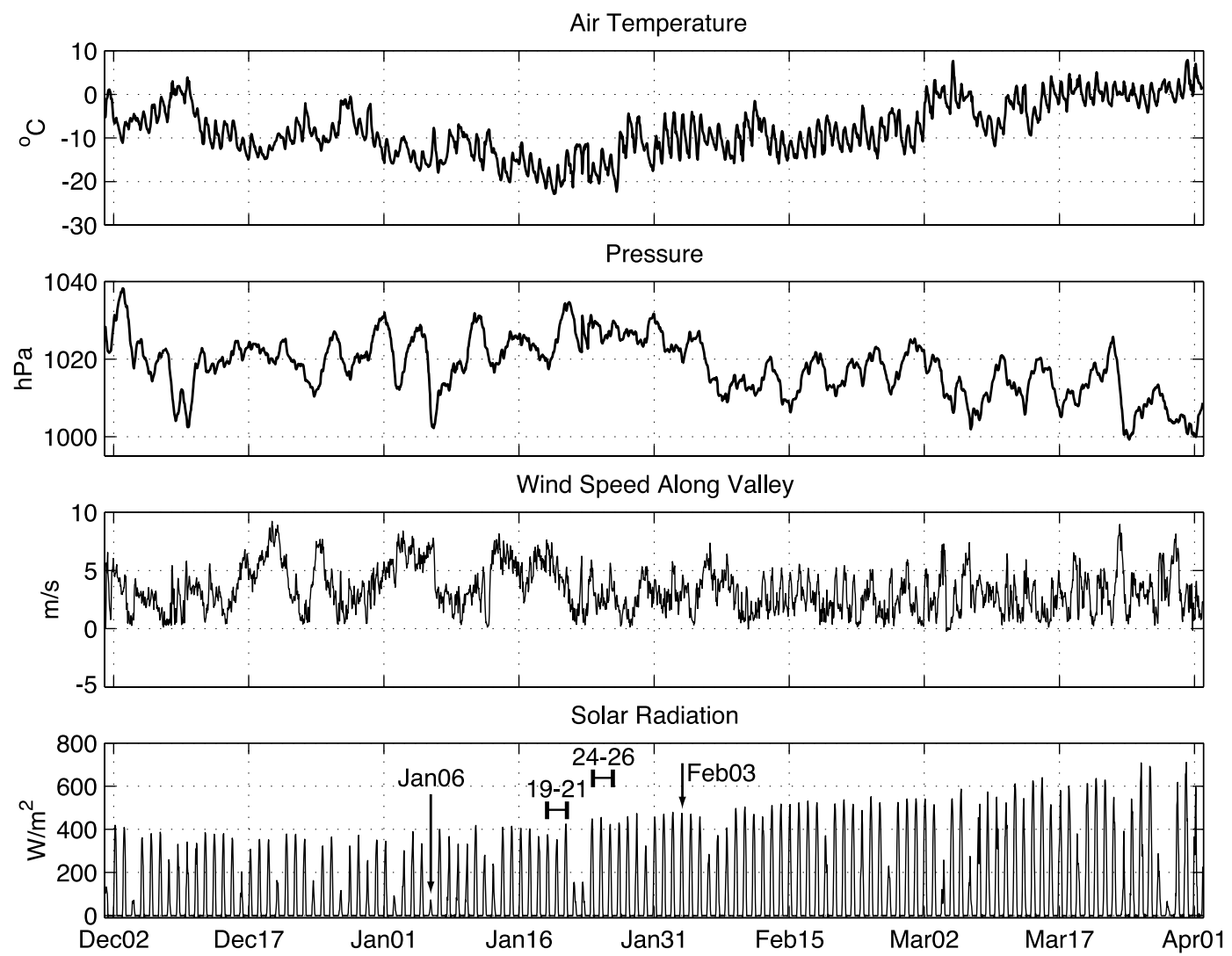

Figure 5. Vladivostok air temperature, pressure, along-valley wind speed, and insolation (incident shortwave radiation) for 1 December 1999 to 1 April 2000. The positive along-valley wind direction is southwest.

and Hozumi and Magono [1984] have investigated convergent cloud bands over the Japan Sea in winter. Both the mean surface-air and the cold air outbreaks crossing the Japan Sea are partially blocked on the southern side by the mountainous Japanese Islands. The result is cold air damming, lifting and greatly increased clouds and rainfall along the south side of the Japan Sea [Dashko and Varlamov, 2000].

\section{The 1999/2000 Winter Conditions}

[21] Winter conditions over the northern Japan Sea are typified by those at the Vladivostok surface station (Figure 5). The air temperature remained below $0^{\circ} \mathrm{C}$ with few exceptions between December 1999 and mid-March 2000. Typical temperatures ranged between $-5^{\circ} \mathrm{C}$ and $-15^{\circ} \mathrm{C}$, with the low of the season being $-21^{\circ} \mathrm{C}$ on $19-$ 20 January 2000 . The air pressure was generally elevated for January and early February when the Siberian High extended farther over the coast. The winds were without extremes $\left(5-8 \mathrm{~m} \mathrm{~s}^{-1}\right)$ and from the northeast, oriented with the Razdol'naya River. It should be noted that winds in the urban area around the SIO/FERHRI station were significantly slower than the more open areas of this river valley. Mostly clear skies allowed the incident solar radiation to be close to that expected for cloudless conditions at this latitude and day of year, with the minimum insolation occurring in late December.
[22] Winter conditions over the southern Japan Sea are typified by the JMA buoy 21002 measurements (not shown). The sea surface temperature decreased rather steadily downward over the period from $17^{\circ} \mathrm{C}$ to less than $10^{\circ} \mathrm{C}$, while the surface-air temperature trended downward from $10^{\circ} \mathrm{C}$ in December to $0^{\circ} \mathrm{C}$ in March. A few days with subzero surface-air temperatures occurred in January and February that were associated with very cold air outbreaks.

[23] Compared to Vladivostok, the air temperature at this buoy was about $20^{\circ} \mathrm{C}$ warmer and the wind speeds peaked up to $15-20 \mathrm{~m} \mathrm{~s}^{-1}$. In addition, the wind direction was only along-valley at Vladivostok, whereas it was from any northern direction at the buoy. The buoy pressure briefly dropped to much lower minima than Vladivostok when the centers of synoptic disturbances passed over the southern Japan Sea.

[24] To compare the winter surface events across the center of the Japan Sea, data collected along the surface transect formed by the Vladivostok station, Roger Revelle, and JMA buoy 21002 are presented in Figure 6 with an expanded scale. The wind speeds tended to be $50 \%$ faster for the ship than the buoy, while Vladivostok was much weaker than both. Finally, insolation (incident short-wave radiation) was greater at Vladivostok, with its tendency for clear skies and offshore air movement, than at the Roger Revelle, where the presence of a well-defined, moist, deep marine boundary layer encouraged boundary layer clouds as 

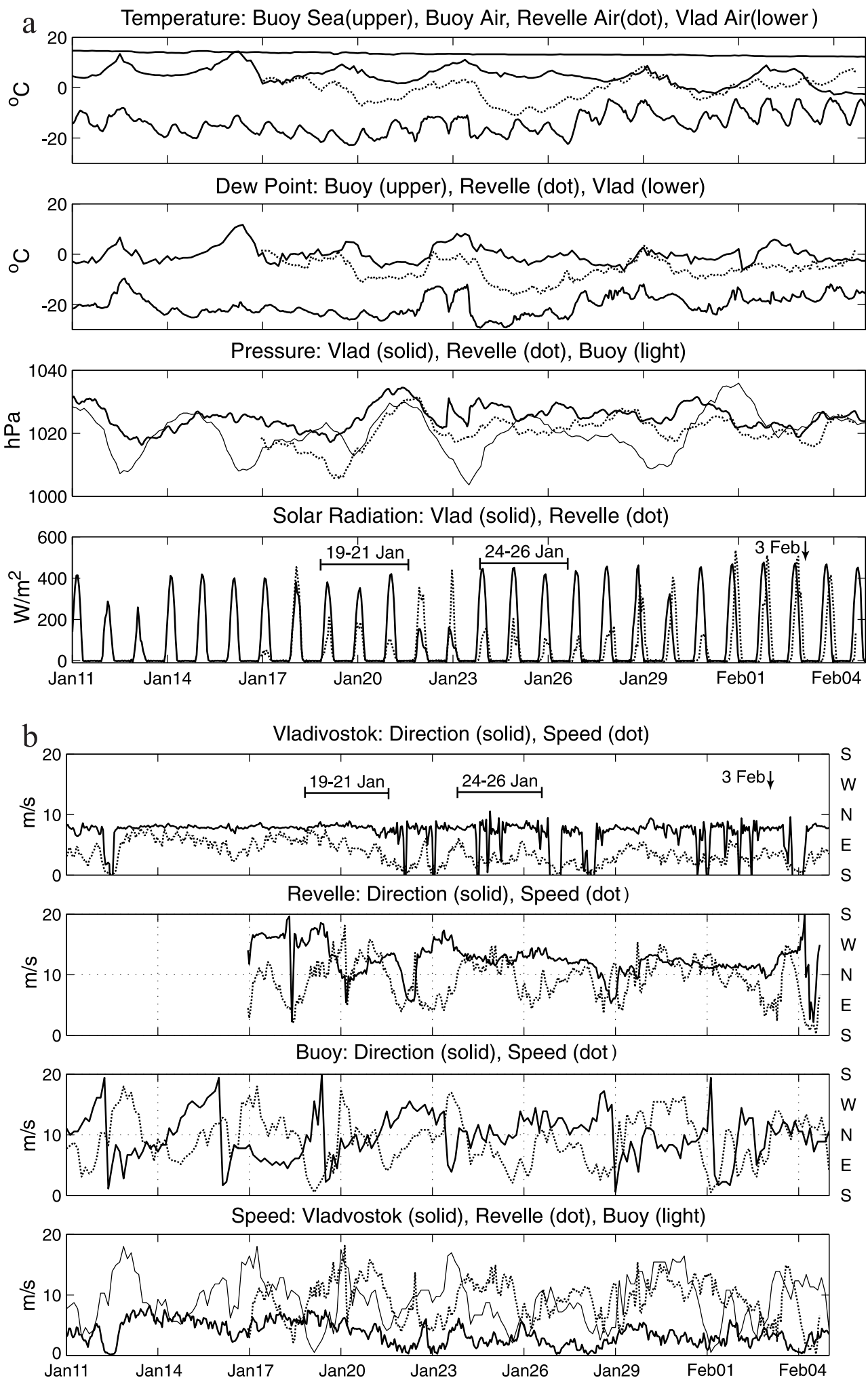

Figure 6. JMA buoy, Revelle, and Vladivostok (a) air temperature, dew point temperature, pressure, and insolation and (b) wind speed and direction for 11 January 2000 to 5 February 2000. 
Table 2. Basic Japan Sea Winter Synoptic Events

\begin{tabular}{|c|c|}
\hline Name & Characteristics \\
\hline Cold Asian Air (CAA) & $\begin{array}{l}\text { originating from northern China interior } \\
\text { land surface temperatures }-15^{\circ} \mathrm{C} \text { to }-10^{\circ} \mathrm{C} \\
0^{\circ} \mathrm{C} \text { sea surface air isotherm north of central Japan Sea } \\
\mathrm{NW}-\mathrm{NE} \text { winds over central Japan Sea } \\
\text { no extensive marine stratus sheet clouds over sea } \\
\text { example: } 3 \text { February } 2000\end{array}$ \\
\hline Very Cold Siberian Air Outbreak (VCSAO) & $\begin{array}{l}\text { originating from eastern Siberia } \\
\text { interior land surface temperatures }-30^{\circ} \mathrm{C} \text { to }-20^{\circ} \mathrm{C} 0^{\circ} \mathrm{C} \\
\text { sea surface air isotherm near Japan } \\
\text { sea level isobars over Russia oriented meridionally } \\
\mathrm{N}-\mathrm{NNE} \text { winds over central Japan Sea } \\
\text { marine stratus sheet clouds over Japan Sea initiating near Russian coast } \\
\text { example: } 24-26 \text { January } 2000\end{array}$ \\
\hline Cyclonic disturbance over southeast Japan Sea & $\begin{array}{l}\text { sea level closed low over southeast Japan Sea } \\
\text { poorly organized marine clouds in early stage. } \\
\text { if cold air outbreak, on west side of low } \\
0^{\circ} \mathrm{C} \text { sea surface isotherm south of } 40^{\circ} \mathrm{N} \\
\text { variable wind direction over central Japan Sea } \\
\text { marine stratus sheet clouds in late stage } \\
\text { example: } 19-21 \text { January } 2000\end{array}$ \\
\hline Cyclonic disturbance over northwest Japan Sea & $\begin{array}{l}\text { sea level closed low over northwest Japan Sea } \\
\text { solid cloud mass over most of Japan Sea } \\
0^{\circ} \mathrm{C} \text { sea surface isotherm near Russian coast } \\
\text { variable wind direction over central Japan Sea } \\
\text { example: } 6 \text { January } 2000\end{array}$ \\
\hline
\end{tabular}
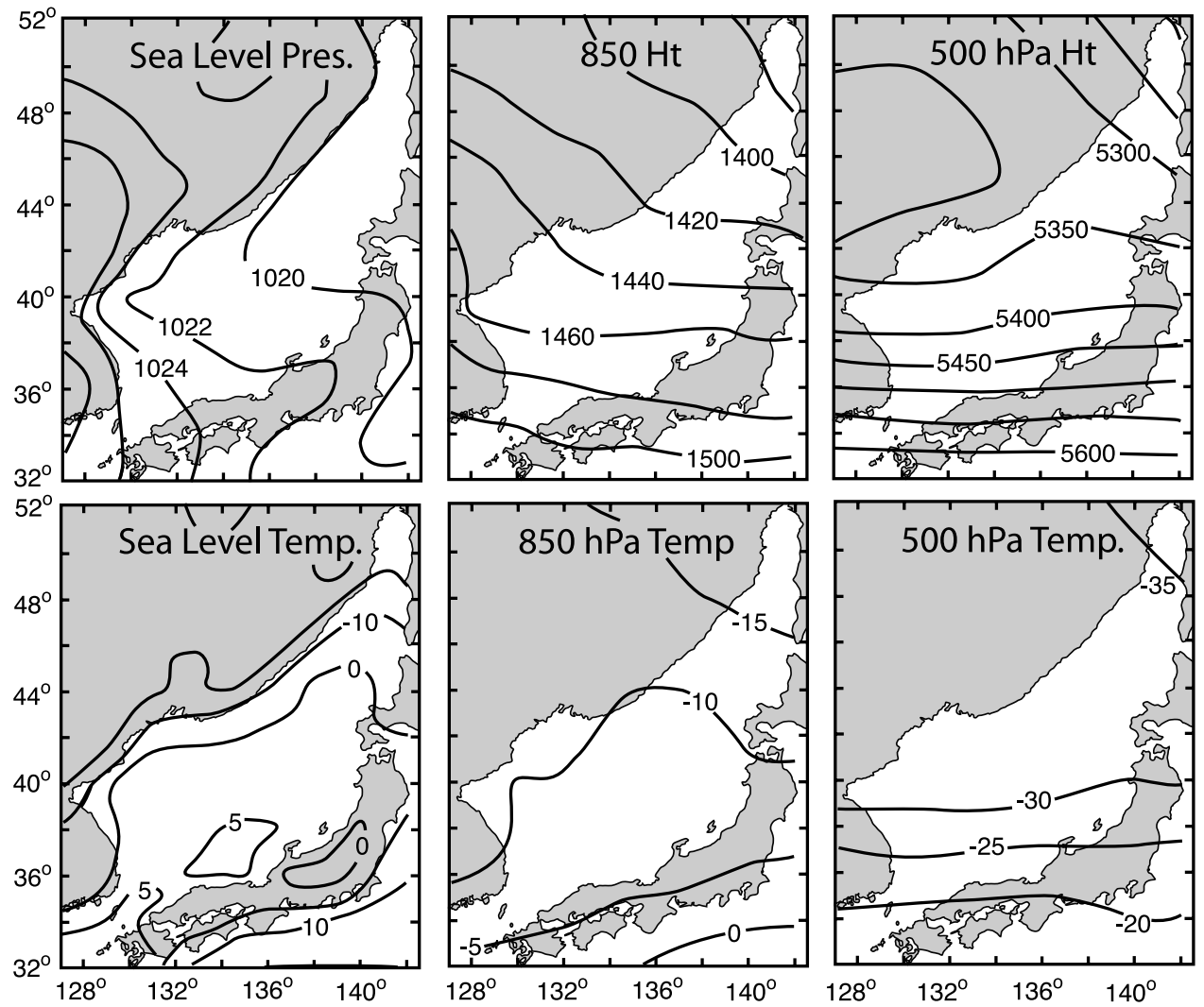

Figure 7. JMA surface analysis for 0000 UTC 3 February 2000. This is typical of mean winter conditions, with sea level isobars oriented NNW-SSE over the Japan Sea. The surface-air temperature $0^{\circ} \mathrm{C}$ isotherm is in the northern half of the Japan Sea. 

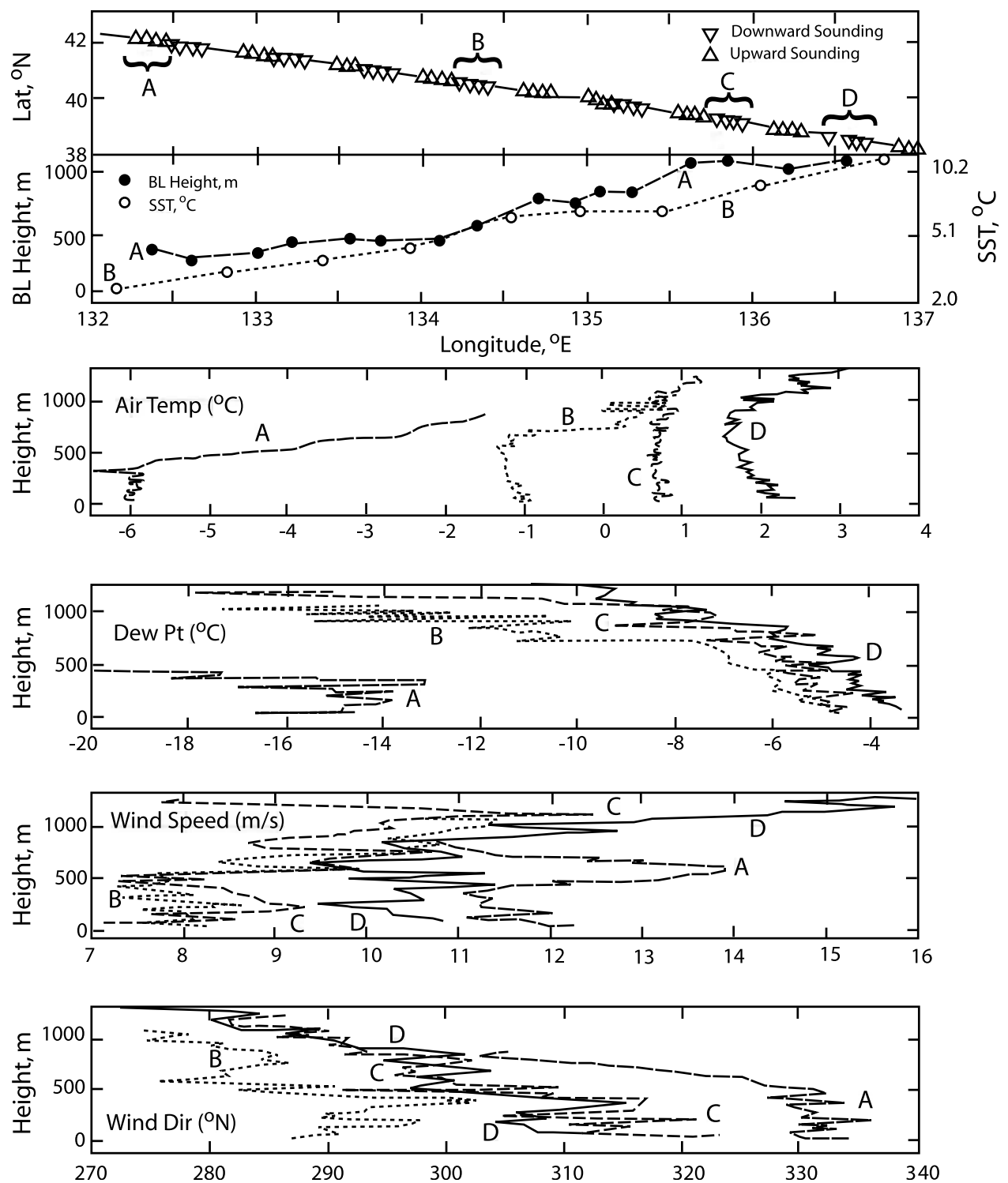

Figure 8. Aircraft sawtooth soundings taken across the center of the Japan Sea on 3 February 2000 beginning near Vladivostok at 0101 UTC and ending near Japan at 0404 UTC. (top to bottom) Geographical positions, boundary layer height and sea surface temperature, selected potential temperature profiles, selected dew point profiles, selected wind speed profiles, and selected wind direction profiles.

well as storm-generated clouds from disturbances that drew warmer air from the south.

\section{Synoptic-Scale Variability}

[25] We found that the 1999/2000 winter conditions over the Japan Sea could be characterized by four basic types of synoptic-scale events (Table 2). The first event type was the dominant winter condition of cold air originating from northern China with the $0^{\circ} \mathrm{C}$ surface-air temperature at or north of $40^{\circ} \mathrm{N}$, and northerly winds in the center of the Japan Sea (Cold Asian Air). The second event type, occurring a few days a month, was the very cold Siberian air outbreak with the $0^{\circ} \mathrm{C}$ surface air-temperature isotherm located over or near Japan and north-northeast winds in the center of the Japan Sea (Very Cold Siberian Air Outbreak). The third type was a weak cyclone passing over the southern Japan Sea with an outbreak of very cold Siberian air on the backside of the low. The fourth event type was a moderate cyclone passing on the northwestern side of the Japan Sea. Fuller descriptions of these characteristic events follow.

\subsection{Cold Asian Air (CAA)}

[26] An example of the dominant CAA event occurred on 3 February 2000. Cold surface air originating from northern China passed over Korea and eastern Russia and then over the Japan Sea. The JMA analysis shows that surface conditions on this day were close to the mean January conditions (Figure 7). At sea level, a high was centered over China and a low, located near the northeastern edge of the Japan Sea, moved east of northern Japan on 4 February. Surface-air temperatures over northern China and eastern Russia were $-15^{\circ} \mathrm{C}$ to $-10^{\circ} \mathrm{C}$. There was a rapid warming 


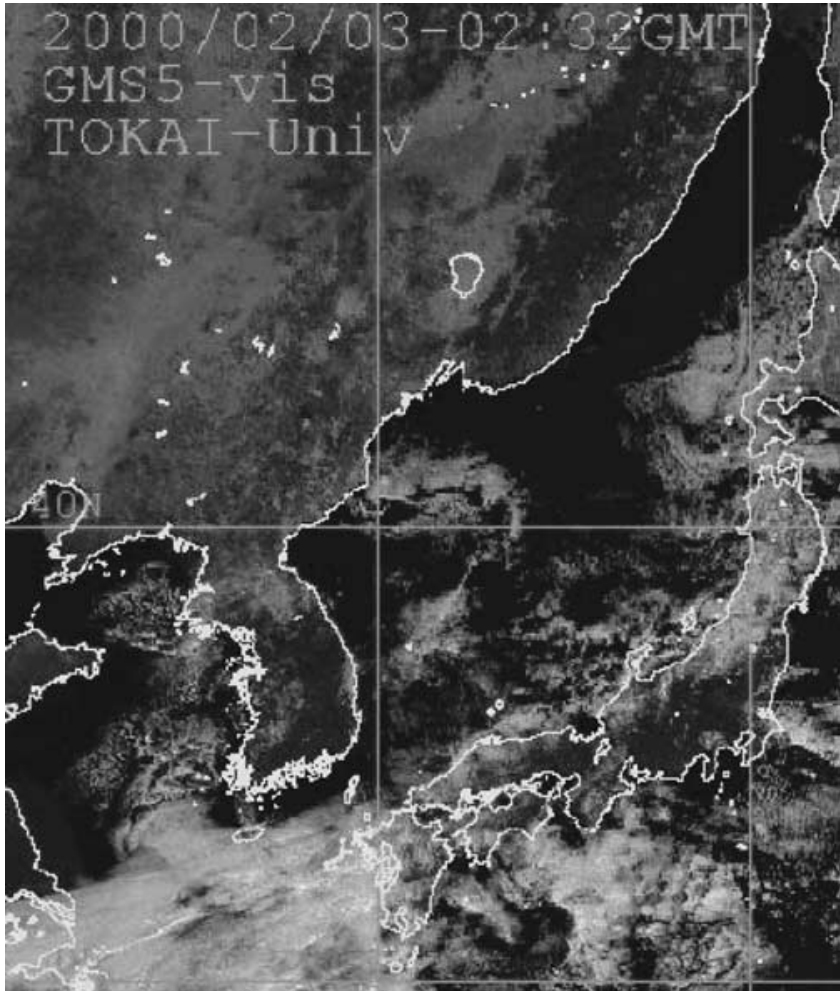

Figure 9. Geostationary satellite visible image at 0232 UTC 3 February 2000.

of surface air from $-10^{\circ} \mathrm{C}$ near the Russian coastal mountaintops to $-5^{\circ} \mathrm{C}$ over the sea, suggestive of lee-side subsidence and adiabatic warming. The $0^{\circ} \mathrm{C}$ surface airtemperature isotherm was located near $40^{\circ} \mathrm{N}-41^{\circ} \mathrm{N}$ in the center of the Japan Sea, slightly north of the January mean. The $850-\mathrm{hPa}$ air temperatures were similar to the surface values over the continent. At $500 \mathrm{hPa}$, the heights were zonal and near average values in the southern majority of the sea, while a low occurred off to the northeast of Japan as seen in the mean conditions.

[27] In Vladivostok (Figure 6a), the surface-air temperature varied between $-15^{\circ} \mathrm{C}$ and $-5^{\circ} \mathrm{C}$, with the daily average about $-10^{\circ} \mathrm{C}$ on 3 February. The dry continental air kept the dew point $5^{\circ} \mathrm{C}$ to $10^{\circ} \mathrm{C}$ less than the surface-air temperature, and the sky was clear. Winds were a weak $2-$ $5 \mathrm{~m} \mathrm{~s}^{-1}$ from the northeast, following the topography. The air in the center of the Japan Sea, as measured by the Roger Revelle, was considerably warmer, being $1^{\circ} \mathrm{C}$ to $4^{\circ} \mathrm{C}$. The winds were northerly at $5 \mathrm{~m} \mathrm{~s}^{-1}$. The incident short-wave radiation was only modestly reduced by a limited cloud cover. At buoy 21002 on the southern side of the Japan Sea, the surface-air temperature was about $5^{\circ} \mathrm{C}$ above freezing, while the sea surface temperature was near $10^{\circ} \mathrm{C}$. Winds were from the north-northeast with speeds around 2$12 \mathrm{~m} \mathrm{~s}^{-1}$ (Figure 6b).

[28] On 3 February, the CIRPAS Twin Otter aircraft flew along a transect from near Vladivostok (starting at $42.1^{\circ} \mathrm{N}$, $132.2^{\circ} \mathrm{E}$ ) across the Japan Sea to near Japan (ending at $\left.38.1^{\circ} \mathrm{N}, 137^{\circ} \mathrm{E}\right)$, making 16 soundings of the marine boundary layer (Figure 8$)$. The near-surface $(\sim 30 \mathrm{~m})$ air temperature and marine boundary layer depth increased from $-6^{\circ} \mathrm{C}$ and $400 \mathrm{~m}$ near the Russian start of the transect, to $-1^{\circ} \mathrm{C}$ and $500 \mathrm{~m}$ in the middle, and to $+2^{\circ} \mathrm{C}$ and $1100 \mathrm{~m}$ at the Japanese end of the transect. Along the same transect, the aircraft-measured infrared sea surface temperature increased from $2^{\circ} \mathrm{C}$ to $7^{\circ} \mathrm{C}$ to $10^{\circ} \mathrm{C}$. However, the wind speeds are fastest $\left(11 \mathrm{~m} \mathrm{~s}^{-1}\right)$ at the northwest end of the flight track with a minimum surface speed between soundings A and B. To the southeast of this point, the surface wind speeds increased from $7 \mathrm{~m} \mathrm{~s}^{-1}$ to $11 \mathrm{~m} \mathrm{~s}^{-1}$, and the surface wind directions turned clockwise, from $290^{\circ}$ to $315^{\circ}$ near Japan.

[29] This aircraft flight shows the trend of marine boundary layer growth and warming away from the immediate vicinity of Russia to Japan during the typical CAA influence. The surface layer wind speeds are fastest closest to Vladivostok, with a minimum marine boundary layer height that is consistent with an expansion fan in the immediate lee. A little farther to the southwest, the trend is for nearsurface wind speeds to increase across the sea toward the southeast in response to the low sea level pressure over Japan. The aircraft measurements show that the $0^{\circ} \mathrm{C}$ surface air-temperature isotherm is near $40^{\circ} \mathrm{N}$ and the sea surface wind direction is from the west to northwest in the central Japan Sea, confirming our identification of this CAA event.

[30] The geostationary satellite visual image on 3 February is clear of clouds along the Russian coast and in the lee, consistent with offshore flow (Figure 9). Over the sea, it was mostly clear with isolated cloud structures along the Japanese coast. No sheet clouds were present, which is also consistent with the marine boundary layer wind speeds and heat flux to the atmosphere being somewhat reduced.

\subsection{Very Cold Siberian Air Outbreak (VCSAO)}

[31] A classic VCSAO took place during 24-26 January 2000. The synoptic-scale structure can be seen in the JMA 1200 UTC analyses for 24-27 January 2000. On 24 January (Figure 10a), the Siberian High moved south, resulting in NNE-SSW oriented isobars over the Russian coast and the Japan Sea, initializing a strong cold air outbreak. The northerly cold air over the Japan Sea continued on 25 January and began to weaken on 26 January when the central pressure and aerial coverage of the Siberian High over the Japan Sea decreased.

[32] The 10-m air temperatures over the continent were coldest $\left(-30^{\circ} \mathrm{C}\right.$ to $\left.-20^{\circ} \mathrm{C}\right)$ on 24 January and increased through 27 January (Figure 10b). On 24 January, the $0^{\circ} \mathrm{C}$ isotherm had shifted to the center of the Japan Sea, and on 25 and 26 January, it was in its southernmost excursion, extending from Korea to mid-Honshu. The $0^{\circ} \mathrm{C}$ isotherm retreated to near $40^{\circ} \mathrm{N}$ on 27 January at the end of the strong, very cold air outbreak.

[33] Over Russia, the $850-\mathrm{hPa}$ air temperatures were below $-30^{\circ} \mathrm{C}$ on 24 January, below $-25^{\circ} \mathrm{C}$ on 25 January, and between $-22^{\circ} \mathrm{C}$ and $-15^{\circ} \mathrm{C}$ on 26 January (Figure $10 \mathrm{c}$ ). On the other hand, the $850-\mathrm{hPa}$ air temperatures over the southern Japan Sea decreased from 24 to the 26 January.

[34] The surface transect across the center of the Japan Sea shows the same trend under very cold air. At Vladivostok (Figure 6a), the surface-air temperature was around $-18^{\circ} \mathrm{C}$ to $-19^{\circ} \mathrm{C}$ on 24 and 25 January, and reached $-20^{\circ} \mathrm{C}$ on 26 January. Winds were weak $\left(3-5 \mathrm{~m} \mathrm{~s}^{-1}\right)$, and the skies were clear. Near the center of the Japan Sea, the Roger Revelle measured air temperatures around $-8^{\circ} \mathrm{C}$ to $-10^{\circ} \mathrm{C}$, and northerly winds with speeds of $10-13 \mathrm{~m} \mathrm{~s}^{-1}$. At buoy 

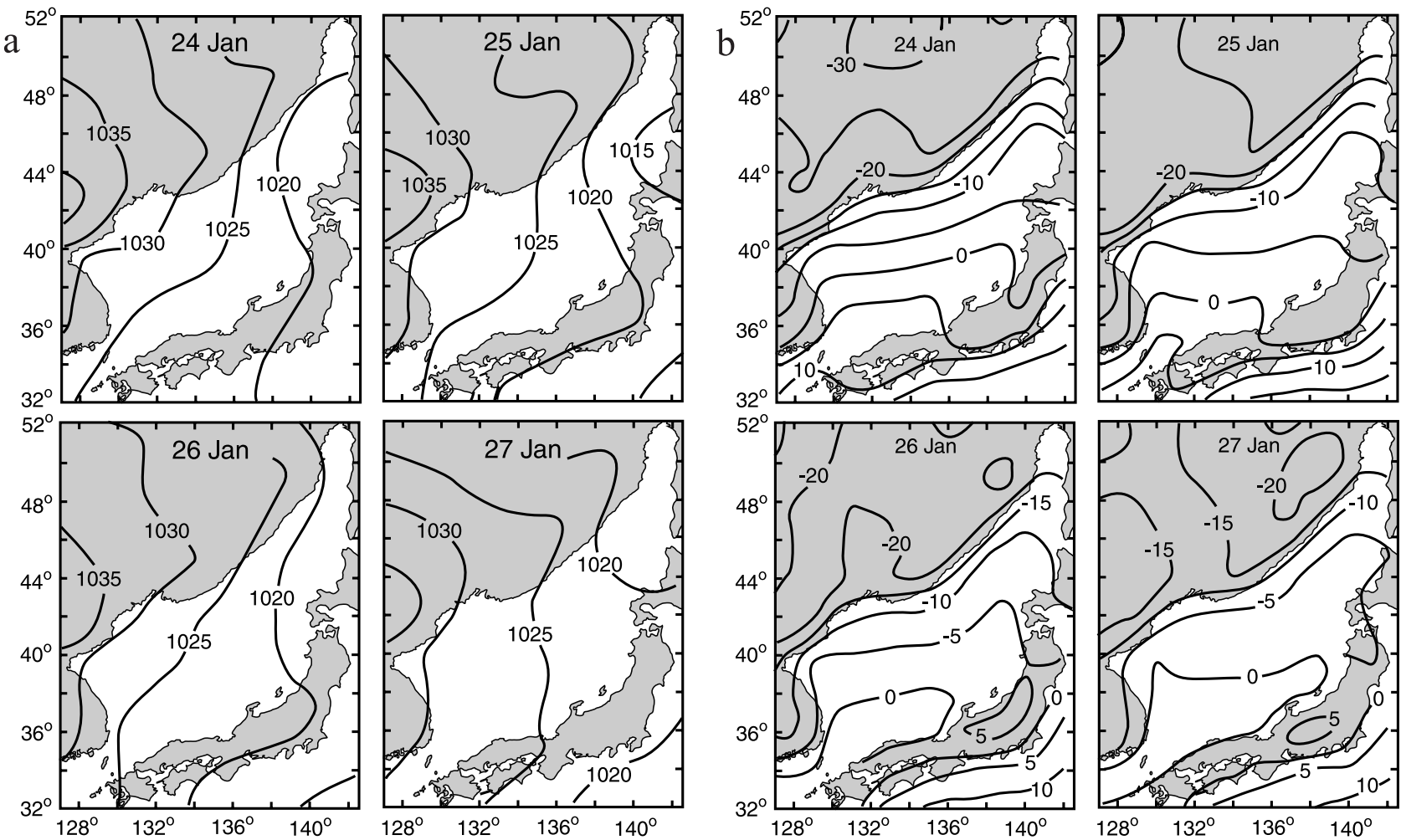
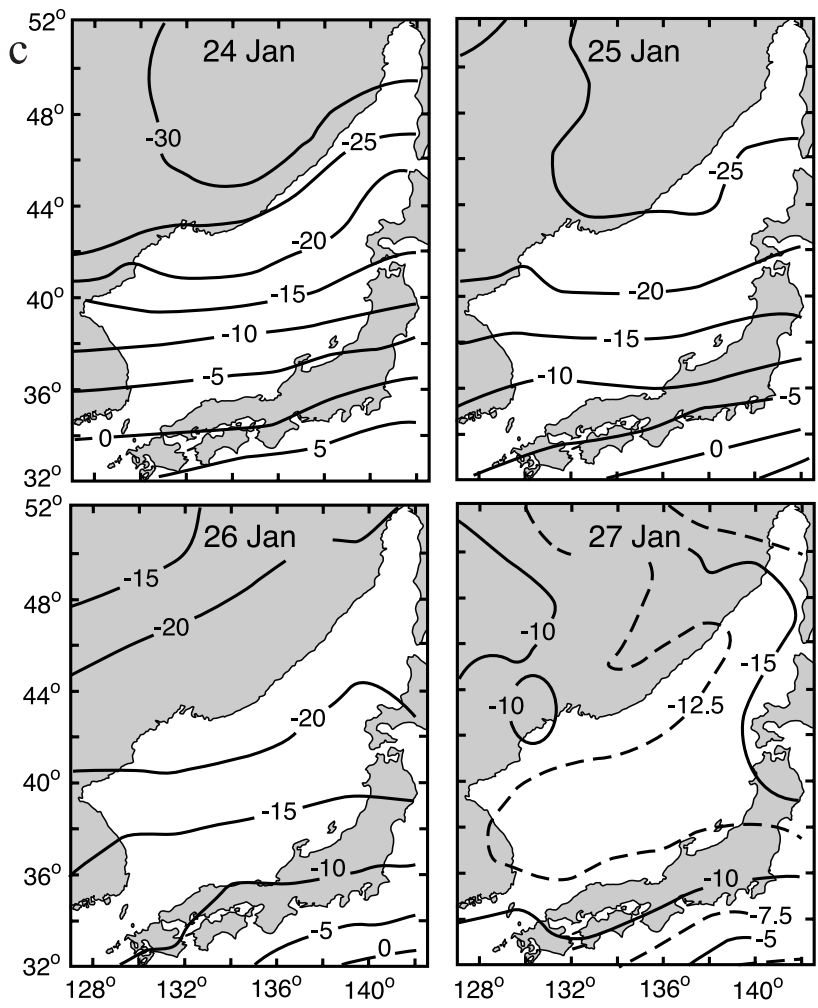

Figure 10. (a) JMA sea level pressure analysis, (b) surface-air temperature $\left({ }^{\circ} \mathrm{C}\right)$, and $850-\mathrm{hPa}$ air temperature $\left({ }^{\circ} \mathrm{C}\right)$ for $0000 \mathrm{UTC}$ on $24-27$ January 2000 . The $0^{\circ} \mathrm{C}$ isotherm is in the southern half of the Japan Sea.

21002, the air temperature was near $0^{\circ} \mathrm{C}$ and was $100 \%$ saturated. Winds were northerly at $10 \mathrm{~m} \mathrm{~s}^{-1}$.

[35] The 0000 UTC Vladivostok soundings confirm that the air mass in the lower atmosphere during 24-26 January
2000 was much colder than the January mean. Even more striking was that a significant ground-based inversion had been eliminated. The low-level stability was greatly reduced so that the potential temperature difference between 1000 

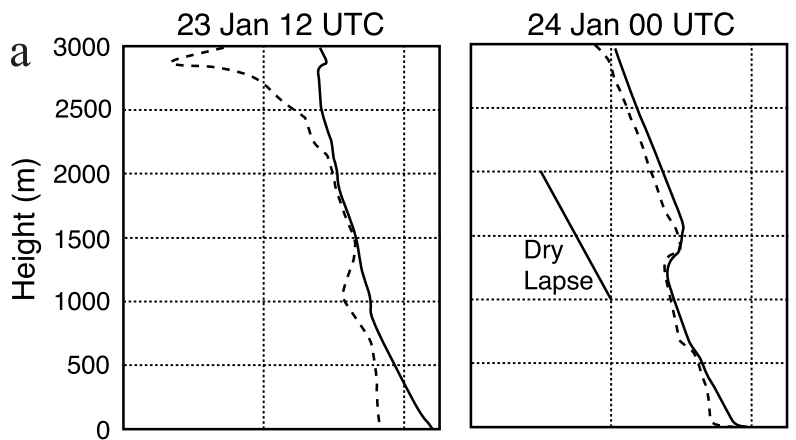

27 Jan 00 UTC

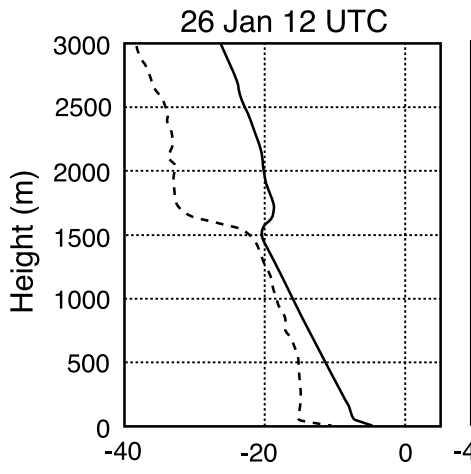

RV Revelle Air Temp (solid - ${ }^{\circ} \mathrm{C}$ ), Dew Point Temp (dash $-{ }^{\circ} \mathrm{C}$ )
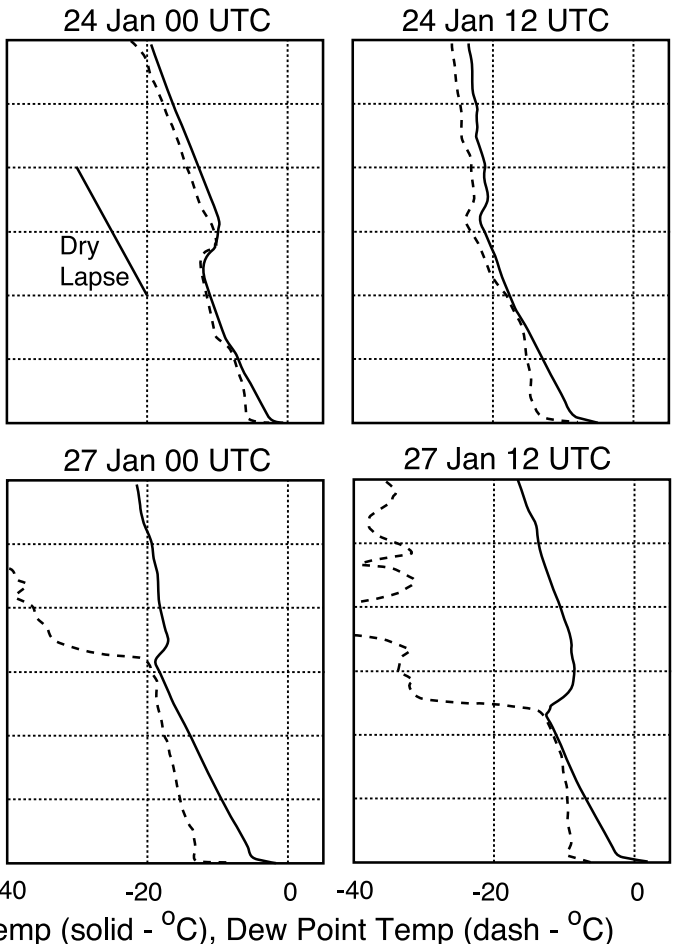

27 Jan 12 UTC

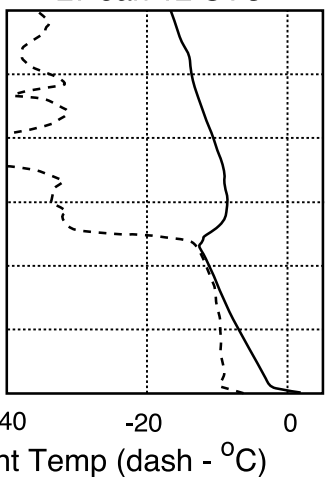

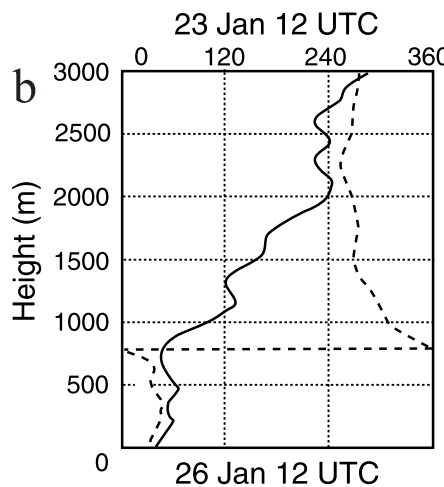

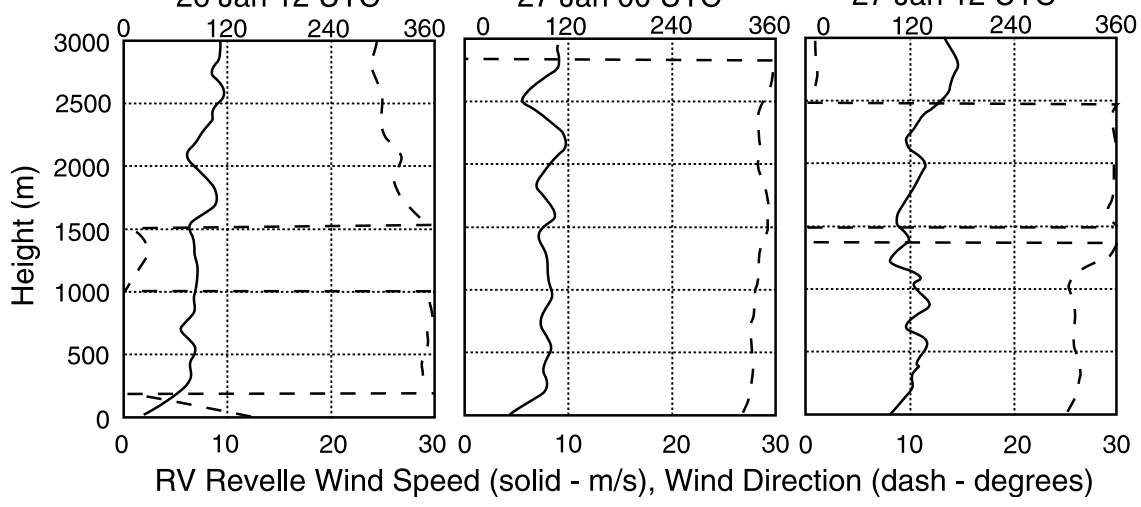

Figure 11. Revelle (a) air temperature and dew point soundings and (b) wind speed and direction taken in the center of the Japan Sea on 23-27 January 2000.

and $850 \mathrm{hPa}$ was only $6.7^{\circ} \mathrm{C}, 6.1^{\circ} \mathrm{C}$, and $4.7^{\circ} \mathrm{C}$, on 24,25 , and 26 January, respectively. Northerly winds exceeded $17 \mathrm{~m} \mathrm{~s}^{-1}$ at $800 \mathrm{~m}$ on all 3 days.

[36] Atmospheric soundings taken on the Roger Revelle in the center of the Japan Sea revealed the lower atmosphere structural changes associated with a cold air outbreak cycle. Before the outbreak at 1200 UTC 23 January, the surface-air temperature was above freezing, the air saturated from 1400 to $2000 \mathrm{~m}$, and dry with a weak inversion above $2000 \mathrm{~m}$ (Figure 11a). On 24 January at 0000 UTC and 1200 UTC, the profiles were nearly saturated while the temperatures fell in the entire column as the cold air outbreak intensified. By 1200 UTC 26 January, the whole column warmed slightly, the near-surface air dried, and subsidence returned above 
a

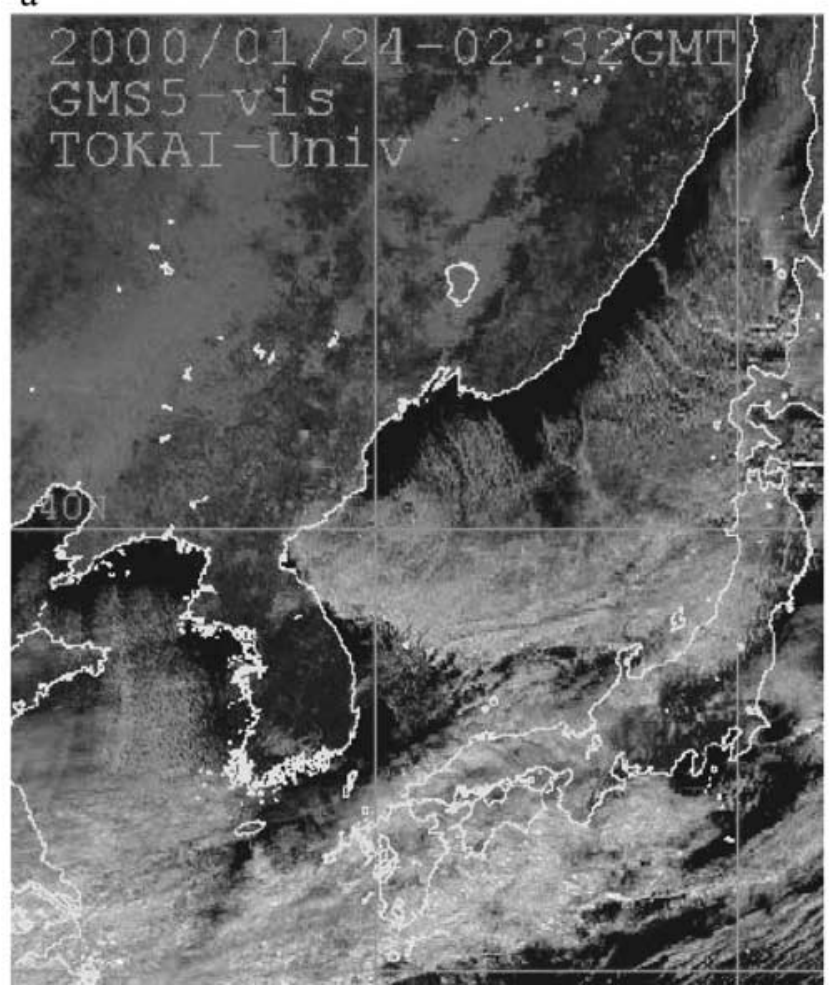

b

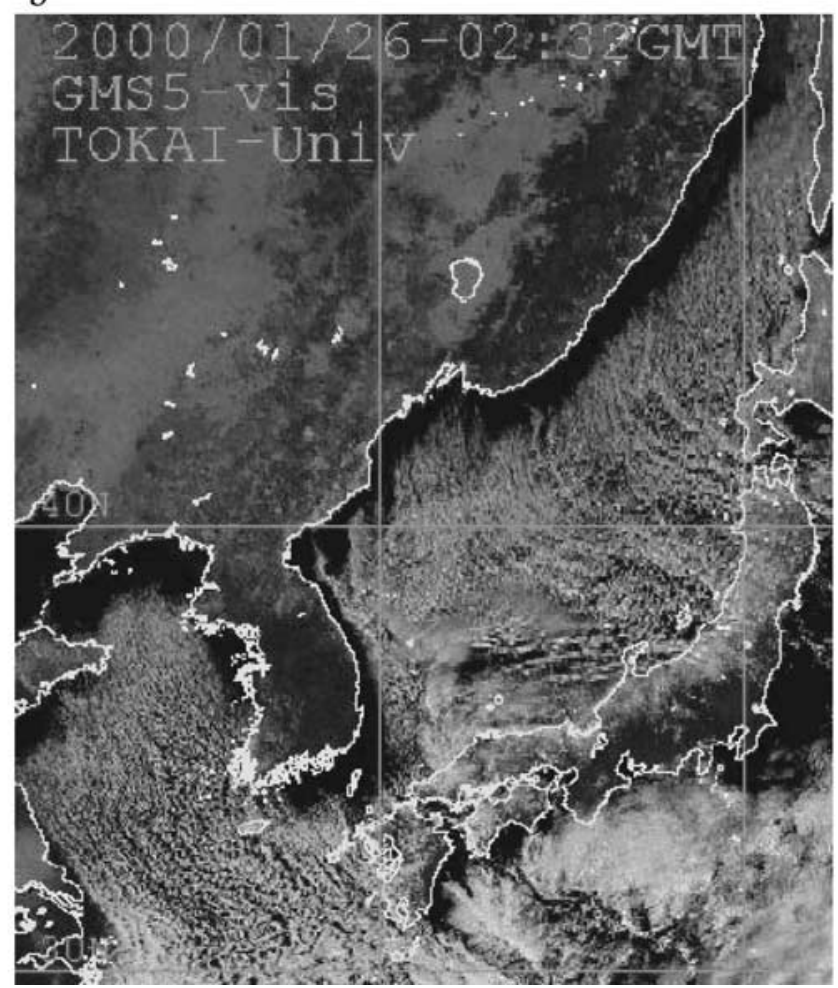

Figure 12. Geostationary satellite visual image for 0232 UTC (a) 24 January 2000 and (b) 26 January 2000.

$1500 \mathrm{~m}$. The weak inversion base marked the top of the sheet clouds. On 27 January, the sea surface temperature and column warmed while the subsidence increased and the subsidence layer dropped to 1200 -m elevation.

[37] The winds associated with the temperatures in Figure 11a are shown in Figure 11b. On 23 and 24 January, strong westerly winds exceeded $20 \mathrm{~m} \mathrm{~s}^{-1}$ above $1500-$ $2000 \mathrm{~m}$. The lowest few hundred meters were first northeast, then NNW and WNW by 1200 UTC 24 January. On 26 January, the winds speeds were all greatly reduced, with the near-surface winds variable in direction. On 27 January at 0000 UTC, the upper winds were weak and the flow from the northwest was below $1500 \mathrm{~m}$. Twelve hours later, the winds were from the north above $1200 \mathrm{~m}$ but rather uniform in speed and from the WNW below $1200 \mathrm{~m}$.

[38] Satellite visual images show sheet clouds filling the Japan Sea during very cold air events. These clouds in the marine boundary layer are caused by roll vortices. They usually form when very cold continental air breaks out over the open sea [House, 1993]. The sheet clouds show both the wind direction and give a cue to the nature of the boundary layer dynamics. Early in this VCSAO event on 24 January (Figure 12a), there was a narrow clearing along the Russian coast, presumably due to the distance that the offshore air mass must travel before the large upward heat flux caused by the warmer sea temperature can overcome the lee-side subsidence. After this point, classical marine sheet clouds lined up with the surface wind.

[39] Two levels of roll vortices formed over the Japan Sea during this event. A few formed a little closer to the coast, and were wider than and above the more uniform sheet clouds that formed farther downstream away from the coast. Upwind land irregularities would appear to have a role in initiating the upper roll vortex clouds, which can be clearly seen above the tops of the smaller roll vortex clouds extending across the Japan Sea to the northern Japanese Island of Hokkaido. There was also a narrow clear area that extended from the southern most point on the Russian coast (southeast of Vladivostok near $42.6^{\circ} \mathrm{N}, 133^{\circ} \mathrm{E}$ ) to halfway across the Japan Sea, reaching $40^{\circ} \mathrm{N}$. Two days later on 26 January (Figure 12b), the sheet clouds more uniformly covered the Japan Sea. The increase of the general cloud mass over Honshu was due to cold air damming, and the abrupt clearing in the lee was more extensive. Cloud lines, caused by the gaps and low points in Honshu, extended far downwind, confirming both that the wind speeds were vigorous and that the air-sea temperature difference remained substantial over the Pacific.

\subsection{Weak Cyclone Over the Southeast Japan Sea}

[40] The third characteristic event type is a weak cyclone (low) that moves over the Japan Sea to the northeast. An example occurred during 18-19 January 2000. At 0000 UTC on 19 January, a low-pressure system was located in the south central Japan Sea (Figure 13a). This system then moved to the east on 20 January and was just off the east side of the chart on 21 January, resulting in meridional isobars over the Japan Sea. Surface-air temperatures on 19 to 21 January over the continent were $-25^{\circ} \mathrm{C}$ to $-20^{\circ} \mathrm{C}$, with rapid warming in the lee of the Russian coastal mountains (Figure 13b). The $0^{\circ} \mathrm{C}$ isotherm over water was near the mean position on 19 January, moved 

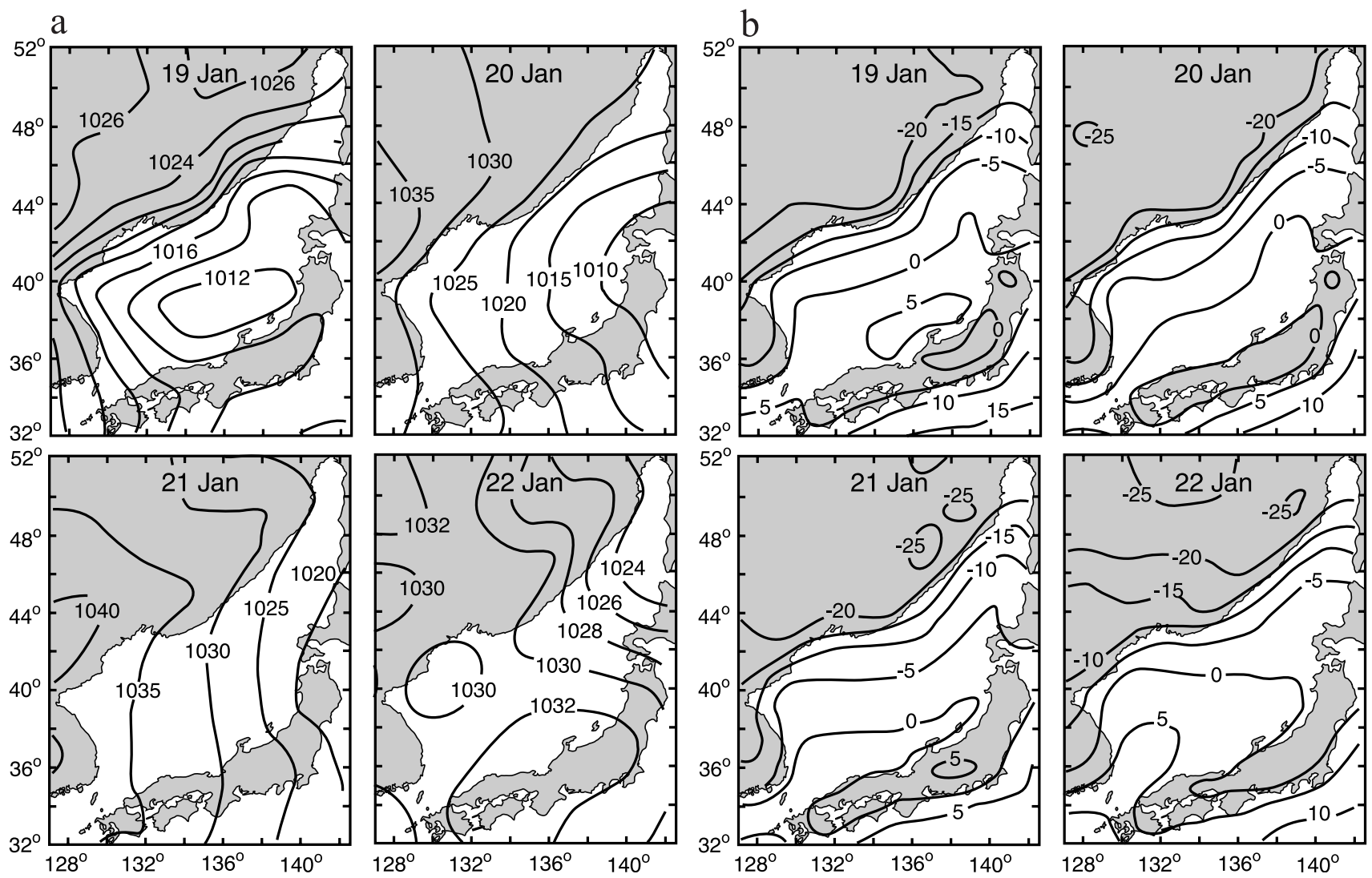

Figure 13. JMA (a) sea level pressure analysis and (b) surface-air temperature $\left({ }^{\circ} \mathrm{C}\right)$ at $0000 \mathrm{UTC}$ for 19-22 January 2000. The closed low over the Japan Sea on 19 January moves to the east of Japan on 20 January. The $0^{\circ} \mathrm{C}$ isotherm is in the central portion of the Japan Sea on 19 January but moves to the southern portion on 21 January.
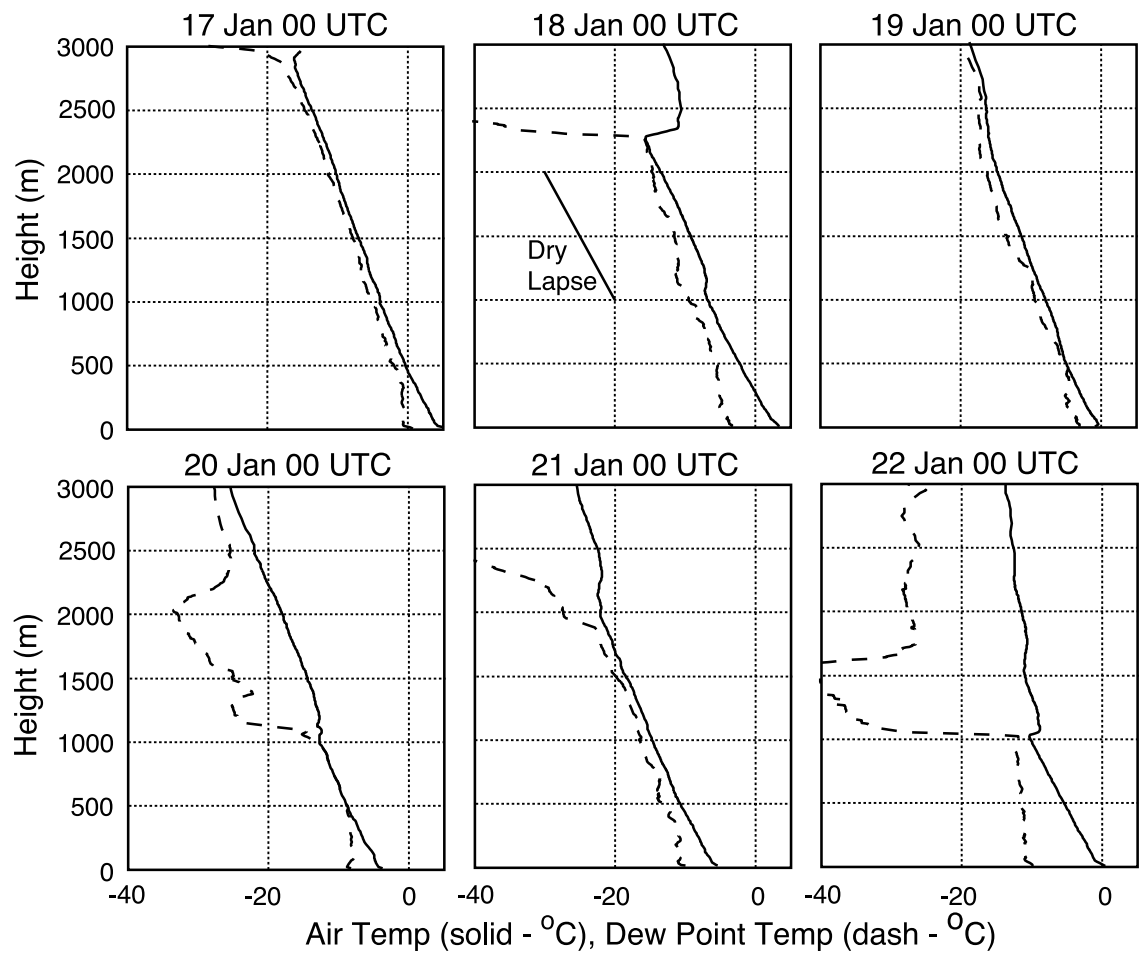

Figure 14. Revelle soundings of air temperature and dew point soundings taken in the center of the Japan Sea on 17-22 January 2000. 
a

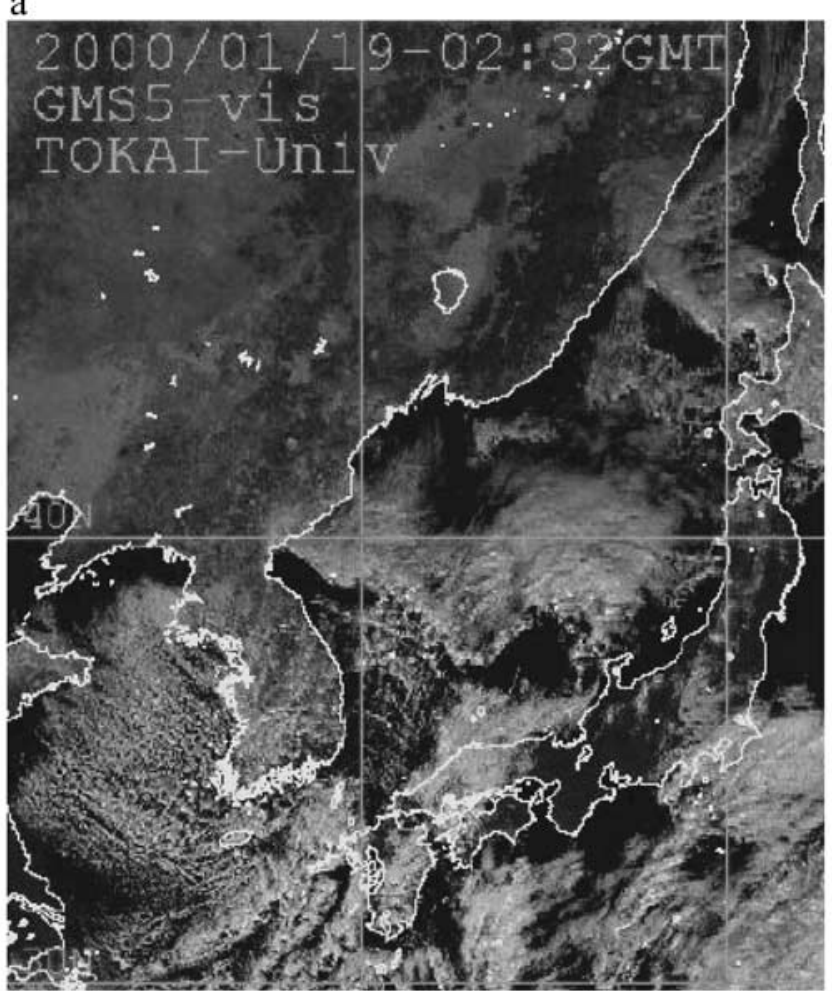

b

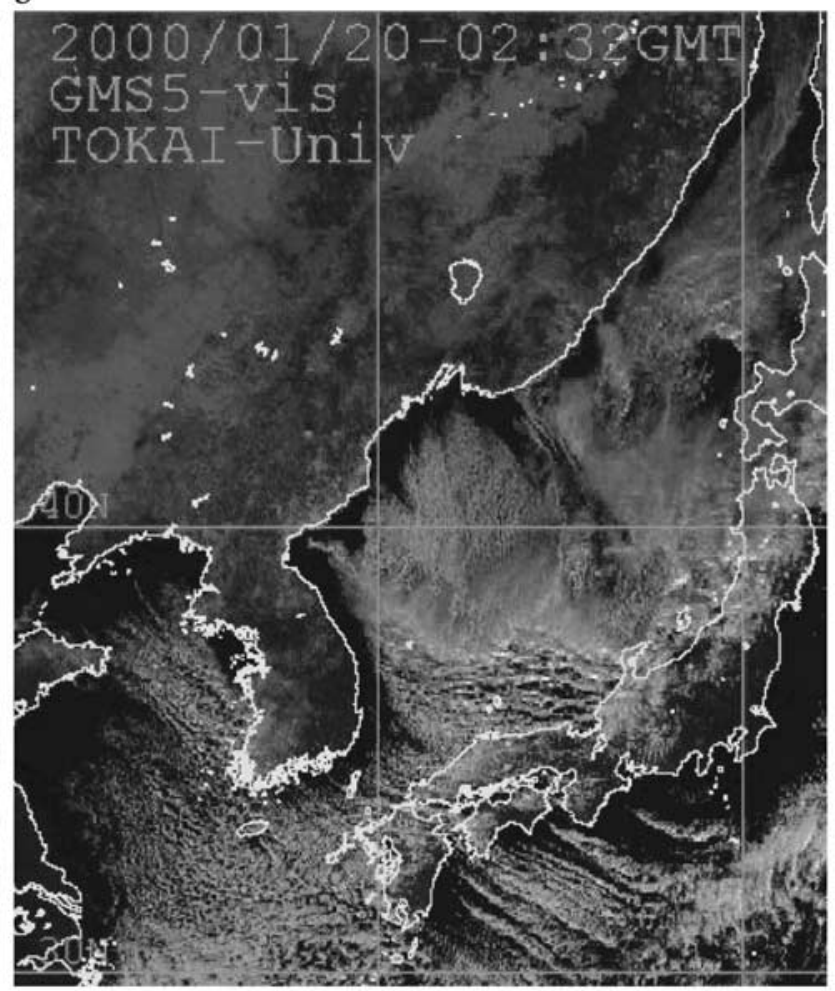

$\mathrm{c}$

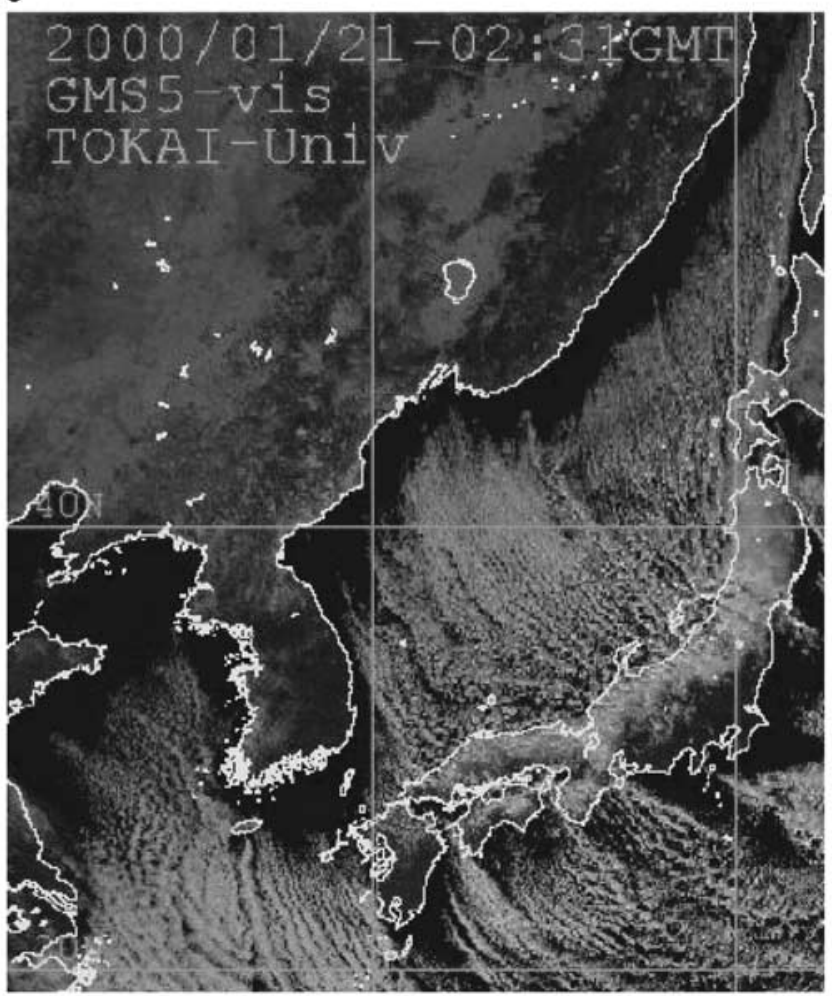

Figure 15. Geostationary satellite visual image for 0232 UTC (a) 19 January 2000, (b) 20 January 2000, and (c) 21 January 2000. In Figure 15b, marine stratus sheet clouds are over the southeast corner of the Japan Sea. In Figure 15c, marine stratus sheet clouds cover the Japan Sea during a VCSAO. 


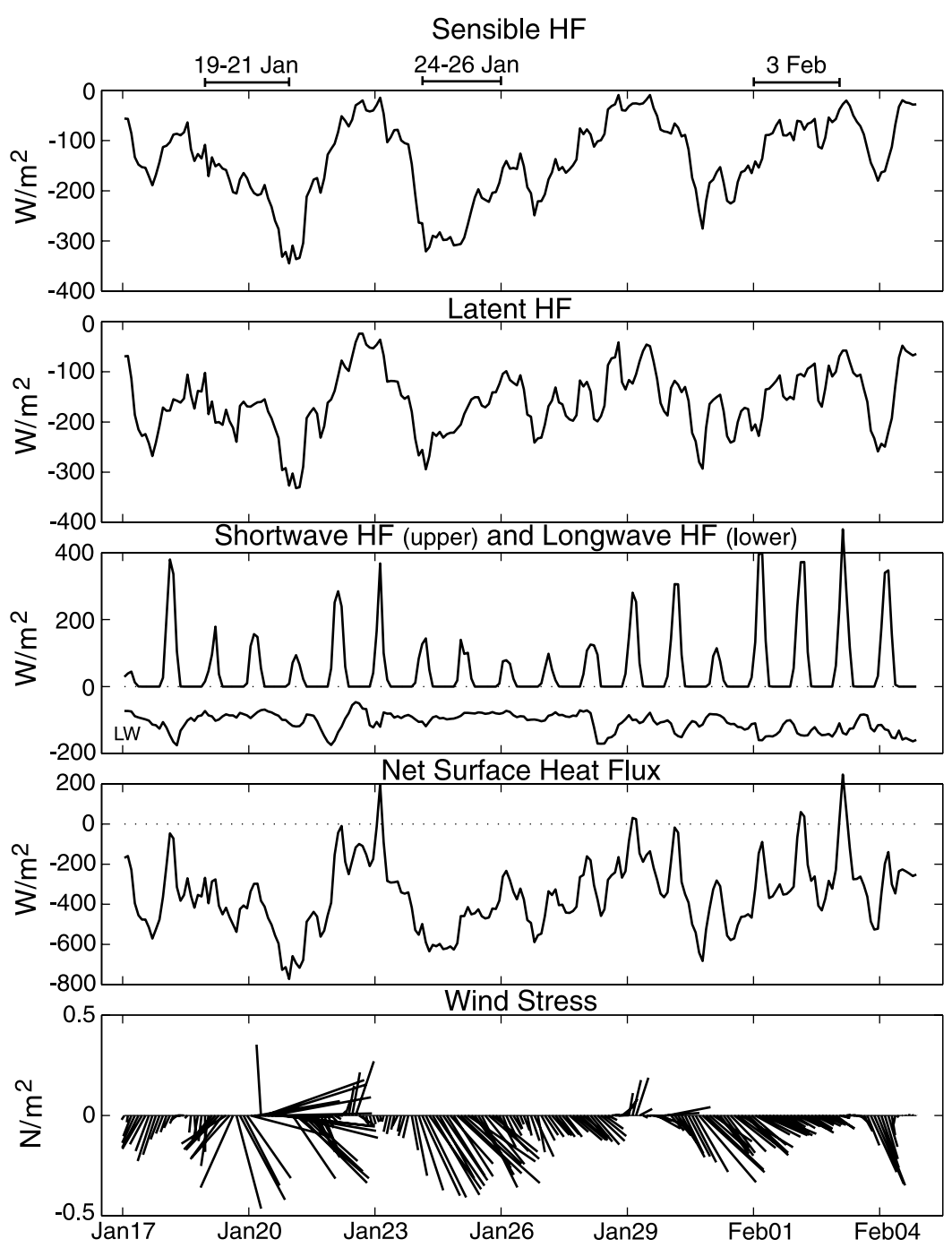

Figure 16. Surface heat flux and wind stress during the Revelle January-February 2000 cruise. Time is UTC.

more to the south on 20 January, and reached its southernmost position on 21 January, then retreated back to the mean position on 22 January. As the low shifted toward the northeast, northerly flow was increased on the back side of the low, increasing northerly flow and a weak cold air outbreak from Siberia.

[41] There were distinctive shifts of sea level conditions across the Japan Sea with these synoptic scale changes. The air temperature at the surface station at Vladivostok at sunrise on 19 January was $-21^{\circ} \mathrm{C}$, which was the lowest temperature measured by this station during this winter. This air had warmed to near zero at the Roger Revelle in the center of the Japan Sea (Figure 6b), and a similar value was recorded at buoy 21002 on the southern side of the sea (Figure 6a). The winds were a modest $7 \mathrm{~m} \mathrm{~s}^{-1}$ from the NNE at Vladivostok, $10-11 \mathrm{~m} \mathrm{~s}^{-1}$ at the Roger Revelle, and $14 \mathrm{~m} \mathrm{~s}^{-1}$ at the buoy (Figure 6b). Wind direction varied from the NNE at Vladivostok, from the WSW at the Roger Revelle, and from the N-NNE at the buoy. While the clear skies allowed the maximum possible insolation at Vladivostok, the clouds associated with this and similar events reduced incident shortwave radiation but increased incident long-wave radiation measured at the Roger Revelle.

[42] The 0000 UTC Vladivostok soundings were nearly isothermal in the low levels on 19-21 January. The 1000- to $850-\mathrm{hPa}$ potential temperature difference was $16.1^{\circ} \mathrm{C}$, $13.1^{\circ} \mathrm{C}$, and $10.5^{\circ} \mathrm{C}$ on 19,20 , and 21 January. The $850-\mathrm{hPa}$ winds were westerly at $9 \mathrm{~m} \mathrm{~s}^{-1}$ on 19 January, northerly at $18 \mathrm{~m} \mathrm{~s}^{-1}$ on 20 January, and $16 \mathrm{~m} \mathrm{~s}^{-1}$ on 21 January.

[43] The boundary layer structure in the center of the Japan Sea during this event was recorded in the atmospheric soundings taken from the Revelle (Figure 14). During 1719 January, the marine air had a near neutral lapse rate and near-surface wind speed of less than $10 \mathrm{~m} \mathrm{~s}^{-1}$. On 20 January, the marine layer was capped by a very dry layer at $1-\mathrm{km}$ elevation, and the surface-air temperature fell to $-3.8^{\circ} \mathrm{C}$. At the same time, the surface wind speed had increased to $18 \mathrm{~m} \mathrm{~s}^{-1}$. On 21 January, the surface-air temperature decreased to $-5.3^{\circ} \mathrm{C}$, and the moist layer had deepened and was capped by a weak inversion at $2 \mathrm{~km}$. The surface winds were $16 \mathrm{~m} \mathrm{~s}^{-1}$ from the northwest, with little 

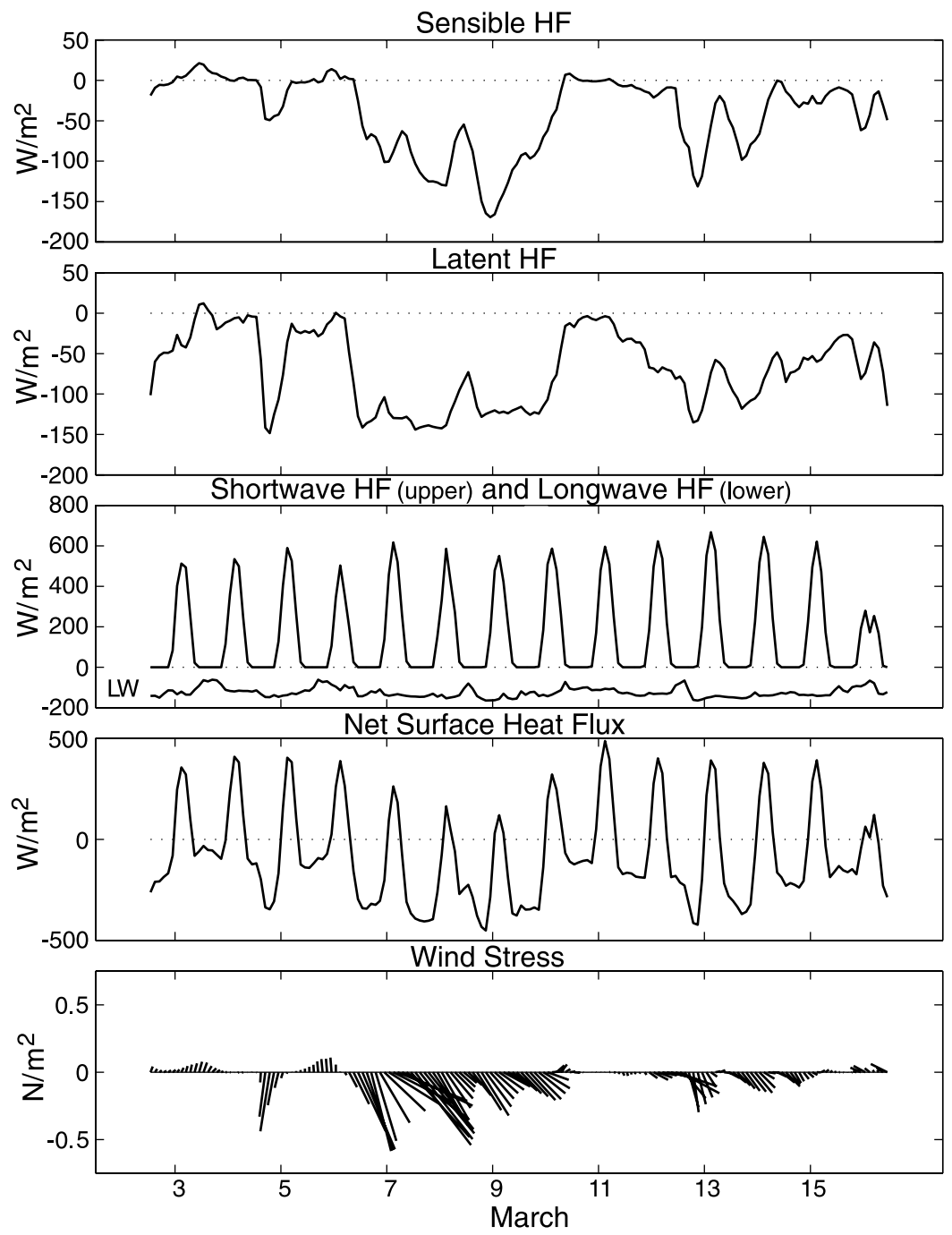

Figure 17. Surface heat flux and wind stress during the Khromov March 2000 cruise. Time is UTC.

change to above $3 \mathrm{~km}$. By 22 January, the surface-air temperature had warmed to above $0^{\circ} \mathrm{C}$.

[44] A solid cloud mass appeared in the center of the Japan Sea on 19 January, coinciding with the surface low (Figure 15a). Otherwise, the cloud field over the sea was rather chaotic. There were some isolated marine sheet clouds (roll vortices) near Korea and in the extreme northern corner of the Japan Sea. On the next day, when the low had moved to the east of Japan, the marine cloud field was more uniform and smooth in the central portion of the sea (Figure 15b). However, on 20 January, there were sheet clouds in the southwest corner of the Japan Sea, extending from Korea across the warm current to Japan. On 21 January, during the VCSAO, the Japan Sea was nearly uniformly covered with sheet clouds extending from the Russian coast to the Japanese coast (Figure 15c).

\subsection{Cyclone Over the Northwest Japan Sea}

[45] The last event type is a moderate cyclone passing over the western portion of the Japan Sea. An example occurred on 6 January, which resulted in the warmest surface-air temperature anomaly that occurred between December 1999 and February 2001 (not shown). The center of the low was just southwest of Vladivostok at 0000 UTC 6 January. The surface-air $0^{\circ} \mathrm{C}$ isotherm was along the Russian coast, an extreme deviation from the monthly mean position through the center of the Japan Sea.

[46] The low extended upward so that at $850 \mathrm{hPa}$ and $500 \mathrm{hPa}$, it was over China. Significantly warmer temperatures were also found at all levels over the Japan Sea. A broad cloud shield covered most of the Japan Sea, with the open portion of a coma cloud centered near $40^{\circ} \mathrm{N}, 131^{\circ} \mathrm{E}$.

\section{Surface Heat Flux}

[47] The net surface heat flux (positive into the ocean) $\left(Q_{\mathrm{NET}}\right)$ is the sum of four components: the net shortwave radiation flux $\left(Q_{\mathrm{SW}}\right)$, the net long-wave radiation flux $\left(Q_{\mathrm{LW}}\right)$, the sensible heat flux $\left(Q_{\mathrm{SEN}}\right)$ due to air-sea temperature differences, and the latent heat flux $\left(Q_{\mathrm{LAT}}\right)$ due to evaporation and condensation. Surface measurements made on the Revelle and Khromov were used to estimate these heat flux components during their respective cruises. The two radiation fluxes were computed using standard methods described by Beardsley et al. [1998] and Pawlowicz et al. [2001]. The sensible and latent fluxes (and wind stress) 

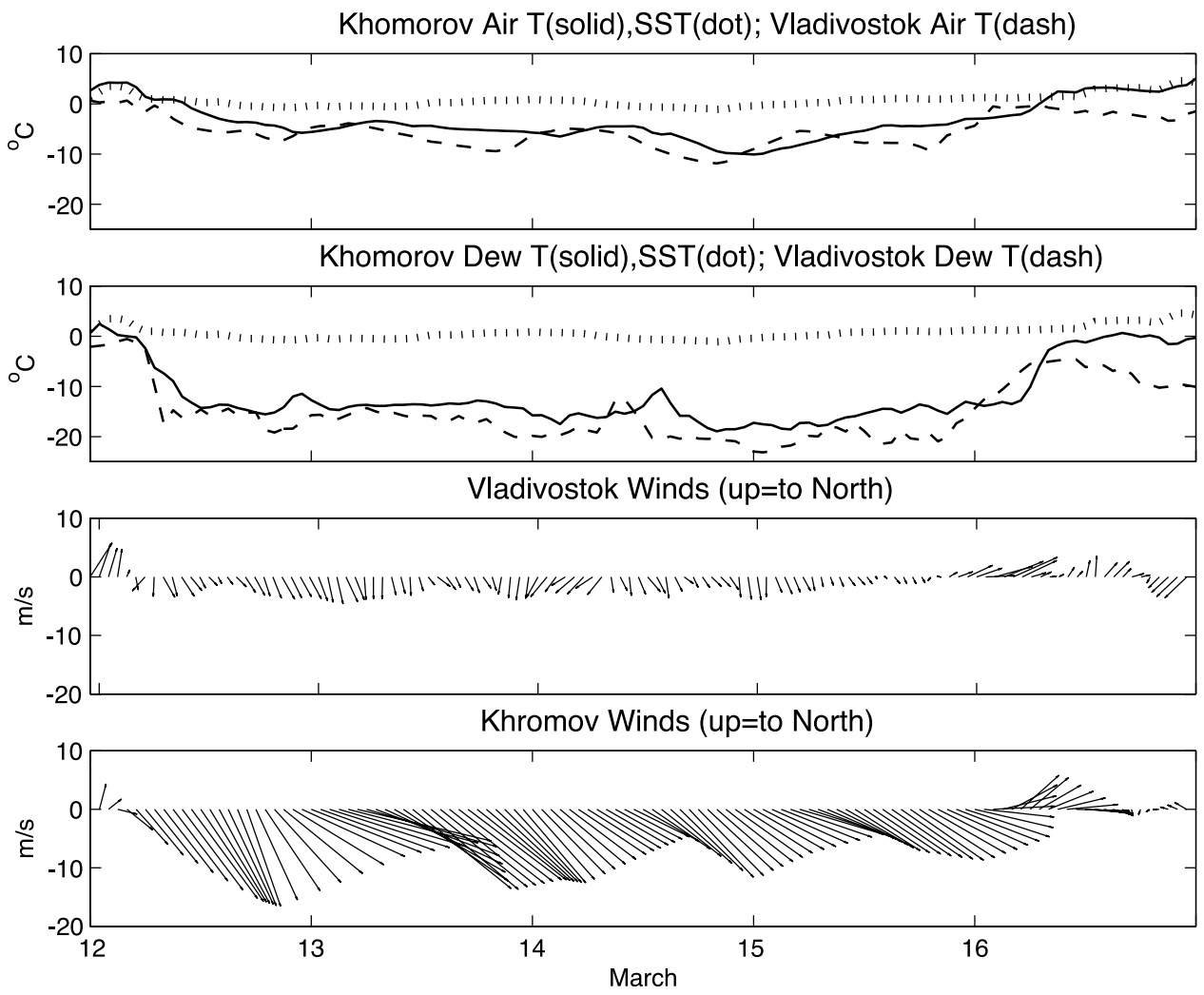

Figure 18. Khromov and Vladivostok winds and temperatures for 12-16 March 2000.

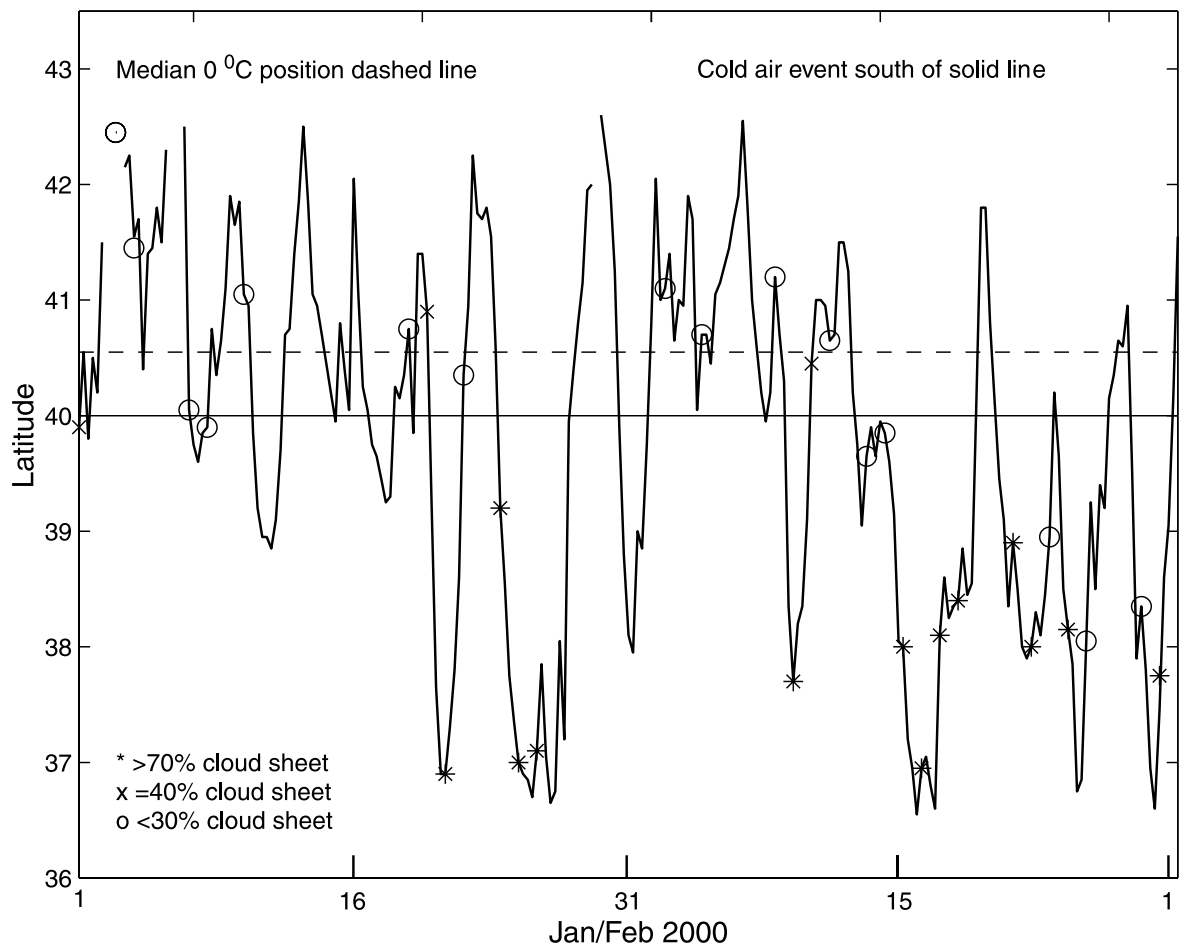

Figure 19. Latitude of the $0^{\circ} \mathrm{C}$ sea surface air-temperature isotherm along $135^{\circ} \mathrm{E}$. Dashed line is the mean position for December 1999 to February 2000. Solid line is the highest latitude for a VCSAO event. Asterisks note occurrence of a cloud sheet covering more than $70 \%$ of the Japan Sea, while crosses indicate $40 \%$ and circles indicate less than $30 \%$ cloud coverage. 
Table 3a. Very Cold Siberian Air Outbreak Event Occurrences ${ }^{\mathrm{a}}$

\begin{tabular}{|c|c|c|c|c|c|c|c|c|c|c|c|c|c|}
\hline & $91 / 92$ & $92 / 93$ & $93 / 94$ & $94 / 95$ & $95 / 96$ & $96 / 97$ & $97 / 98$ & 98/99 & $99 / 00$ & $00 / 01$ & $01 / 02$ & Sum & Average \\
\hline Nov. & 0 & 1 & 0 & 0 & 0 & 1 & 0 & 1 & 0 & 1 & 2 & 6 & 0.5 \\
\hline Dec. & 2 & 1 & 4 & 1 & 3 & 3 & 3 & 3 & 0 & 7 & 6 & 33 & 3.0 \\
\hline Jan. & 3 & 3 & 5 & 4 & 5 & 6 & 8 & 5 & 8 & 4 & 6 & 57 & 5.2 \\
\hline Feb. & 4 & 0 & 3 & 0 & 4 & 6 & 4 & 5 & 5 & 3 & 3 & 37 & 3.4 \\
\hline March & 1 & 0 & 2 & 0 & 0 & 3 & 0 & 5 & 1 & 2 & 1 & 15 & 1.4 \\
\hline Year & 10 & 5 & 14 & 5 & 12 & 19 & 15 & 19 & 14 & 17 & 18 & 148 & 13.5 \\
\hline
\end{tabular}

${ }^{\mathrm{a}}$ Numbers in column headings are given as yy/yy.

were computed using the COARE 2.6a bulk algorithm described by Bradley et al. [2000] and Fairall et al. [2003]. This code was developed and tested for a broad set of nonequatorial conditions that include those observed in the Japan Sea during winter. Based on uncertainties of $5 \%$ in $Q_{\mathrm{SW}}, 10 \mathrm{~W} \mathrm{~m}^{-2}$ in $Q_{\mathrm{LW}}$, and $7 \%$ in $Q_{\mathrm{SEN}}$ and $Q_{\mathrm{LAT}}$, the uncertainties in $Q_{\mathrm{NET}}$ are $19 \mathrm{~W} \mathrm{~m}^{-2}$ for the Revelle winter cruise and $14 \mathrm{~W} \mathrm{~m}^{-2}$ for the Khromov winter cruise.

\subsection{Revelle Heat Flux}

[48] The net surface flux and its components exhibited large variability on timescales from several hours to synoptic (2-8 day) events during the Revelle cruise (Figure $16)$. The mean fluxes over the 19-day cruise were: $Q_{\mathrm{NET}}=$ $-375 \mathrm{~W} \mathrm{~m}^{-2} ; Q_{\mathrm{SW}}=53 \mathrm{~W} \mathrm{~m}^{-2} ; Q_{\mathrm{LW}}=-107 \mathrm{~W} \mathrm{~m}^{-2}$; $Q_{\mathrm{SEN}}=-153 \mathrm{~W} \mathrm{~m}^{-2}$; and $Q_{\mathrm{LAT}}=-168 \mathrm{~W} \mathrm{~m}^{-2}$. Much of this heat loss was due to the sensible and latent fluxes, which ranged from roughly 0 to $-350 \mathrm{~W} \mathrm{~m}^{-2}$ on synoptic event scales. The surface downward shortwave flux was generally lessened by marine clouds, which also reduced the net outgoing long-wave heat flux. The net flux varied from $-900 \mathrm{~W} \mathrm{~m}^{-2}$ to $+200 \mathrm{~W} \mathrm{~m}^{-2}$, but was mostly negative, indicating that the central part of the Japan Sea was losing heat during most of the Revelle's 17-day cruise.

[49] The largest net heat flux losses occurred on 21, 24, and 30 January. The large loss on 24 January is expected since it occurred during the very cold Siberian air outbreak (VCSAO) described in section 4.2. The large loss on 21 January also occurred during a strong cold air event. However, the large loss on 30 January occurred at night during northwest flow and without roll clouds, indicating that cold dry air was moving rapidly across the sea. It appears then that simple northwest flow events are just as capable of extracting large amounts of heat from the Japan Sea as are cold air outbreak events.

\subsection{Khromov Heat Flux}

[50] The surface heat flux and its components during the Khromov 2-16 March 2000 cruise also exhibited significant variability on hourly to synoptic timescales (Figure 17).
The mean fluxes over this 14-day cruise were: $Q_{\mathrm{NET}}=$ $-86 \mathrm{~W} \mathrm{~m}^{-2} ; Q_{\mathrm{SW}}=157 \mathrm{~W} \mathrm{~m}^{-2} ; Q_{\mathrm{LW}}=-125 \mathrm{~W}$ $\mathrm{m}^{-2} ; Q_{\mathrm{SEN}}=-45 \mathrm{~W} \mathrm{~m}^{-2}$; and $Q_{\mathrm{LAT}}=-73 \mathrm{~W} \mathrm{~m}^{-2}$. As it was late in the winter season, the sensible and latent heat fluxes were weaker and the maximum losses were a factor of 2 less than during the earlier Revelle cruise. The seasonal increase in insolation and decreased cloud cover along the northwestern side of the Japan Sea both contributed to a larger net downward shortwave heat flux. The net longwave loss changed little from the Revelle cruise.

[51] These changes resulted in a significant net heat gain by the sea during daylight hours. The Khromov cruise track (Figure 1) began in Korea. The largest daily net heat losses were over $100 \mathrm{~W} \mathrm{~m}^{-2}$ on $6 \mathrm{March}$, and over $200 \mathrm{~W} \mathrm{~m}^{-2}$ on 7, 8, and 9 March, all of which occurred when the Khromov was south or southeast of Vladivostok. A second, smaller daily heat loss of about $100 \mathrm{~W} \mathrm{~m}^{-2}$ occurred on 12 and 13 March when the Khromov was off the northern Russian coast.

[52] A comparison of the Vladivostok and Khromov meteorological data reveals the strong, offshore wind speed gradients that caused the largest heat losses measured by the Khromov (not shown). For example, a weak wind increase to a few m s${ }^{-1}$ at Vladivostok peaked to more than $20 \mathrm{~m} \mathrm{~s}^{-1}$ at the Khromov on 6 March. Also causing heat loss was the very dry offshore air with dew points down to $-15^{\circ} \mathrm{C}$ to $-20^{\circ} \mathrm{C}$. In contrast to the wind speed, the air temperatures and dew points at the two stations were similar, with the tendency for both to be a few degrees higher at the Khromov. During this period, the sea surface temperature changed little over this area, remaining near freezing. The coldest sea surface temperature was $-1.3^{\circ} \mathrm{C}$ while the coldest air temperature was $-10.3^{\circ} \mathrm{C}$.

[53] There is a tendency for air flowing offshore over the more northern Russian coast to be warmer and drier than at Vladivostok. This is shown in Figure 18 with a comparison of data from both stations for 12-15 March when the Khromov was along the open coast. The air temperature was as much as $5^{\circ} \mathrm{C}$ warmer and the dew point as low as $10^{\circ} \mathrm{C}$ less in the lee of the Russian coast during stronger

Table 3b. Very Cold Siberian Air Outbreak Event Duration (in Days)

\begin{tabular}{rcccccccccrrrr}
\hline & $91 / 92$ & $92 / 93$ & $93 / 94$ & $94 / 95$ & $95 / 96$ & $96 / 97$ & $97 / 98$ & $98 / 99$ & $99 / 00$ & $00 / 01$ & $01 / 02$ & Sum & Average \\
\hline Nov. & 0 & 1.0 & 0 & 0 & 0 & 1.5 & 0 & 1.0 & 0 & 1.75 & 7.2 & 7.2 & 0.7 \\
Dec. & 3.0 & 1.7 & 6.5 & 5.7 & 5.2 & 6.2 & 6.2 & 9.7 & 0 & 23.50 & 27.0 & 95.5 & 8.7 \\
Jan. & 8.2 & 4.7 & 19.5 & 15.0 & 16.2 & 21.5 & 22.7 & 19.7 & 17.5 & 18.75 & 18.5 & 182.5 & 16.6 \\
Feb. & 7.5 & 0 & 1.0 & 0 & 12.7 & 13.2 & 7.0 & 9.5 & 20.5 & 20.75 & 9.5 & 110.7 & 10.1 \\
March & 1.0 & 0 & 3.0 & 0 & 0 & 3.5 & 0 & 8.5 & 3.5 & 8.75 & 2.0 & 30.2 & 2.7 \\
Year & 19.7 & 7.5 & 39.0 & 20.7 & 34.2 & 46.0 & 36.5 & 48.5 & 41.5 & 73.50 & 59.0 & 426.2 & 38.7 \\
\hline
\end{tabular}

${ }^{\mathrm{a}}$ Numbers in column headings are given as yy/yy. 

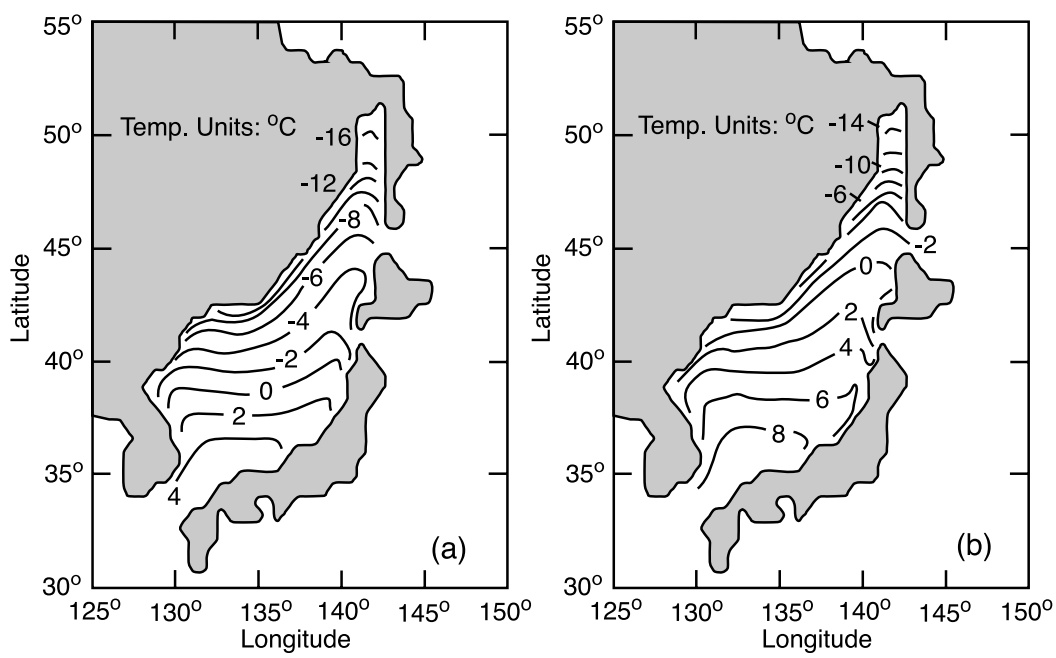

Figure 20. Average spatial structure of the near-surface air temperature (a) during VCSAO events and (b) during non-VCSAO event periods.

offshore winds as experienced by the Khromov. The difference can be partly explained by lee-side warming downwind of the mountainous northern Russian coast, not experienced by Vladivostok. Instead, Vladivostok receives cooler air flowing along the lower elevations of the Razdol'naya River valley.

\section{Average Structure of VCSAO Events}

[54] The most distinguishing feature in our Japan Sea winter observations is the Very Cold Siberian Air Outbreak (VCSAO). Here we use ECMWF analyses for the period 1991-2002 to construct a composite "average" VCSAO event and use this to place our 1999/2000 winter results in the context of this 11-year period. The mean atmospheric conditions and surface fluxes for 1991-2002 are shown by Dorman et al. (submitted manuscript, 2004).

[55] On the basis of our 1999/2000 winter observations and the experience of regional operational forecasters, a cold air event occurrence is characterized by the latitude of the $0^{\circ} \mathrm{C}$ surface air-temperature isotherm along $135^{\circ} \mathrm{E}$. Using the ECMWF analysis, the mean position for December 1999 to February 2000 is $40.6^{\circ} \mathrm{N}$. The position for January-February 2000 is plotted in Figure 19 along with a satellite image cloud sheet characterization for the mid-day pass (Table 4 in section 8). All cases of extensive cloud sheets covering $>70 \%$ of the Japan Sea occurred when the $0^{\circ} \mathrm{C}$ air temperature along $135^{\circ} \mathrm{E}$ is well south of $40^{\circ} \mathrm{N}$. On the other hand, $66 \%$ of the cases with less than $30 \%$ cloud sheet coverage occurred when the $0^{\circ} \mathrm{C}$ isotherm was close to $40^{\circ} \mathrm{N}$ or farther north.

[56] Here we define a VCSAO event as occurring when the $0^{\circ} \mathrm{C}$ isotherm along $135^{\circ} \mathrm{E}$ is south of $40^{\circ} \mathrm{N}$ for 24 hours or longer. For 1991-2002, such defined events only occurred between 20 November and 28 March (Table 3a). The bulk of these events occur in December-February, with a peak monthly mean of 5.2 events in January. The total number of events in a season (November-March) ranges
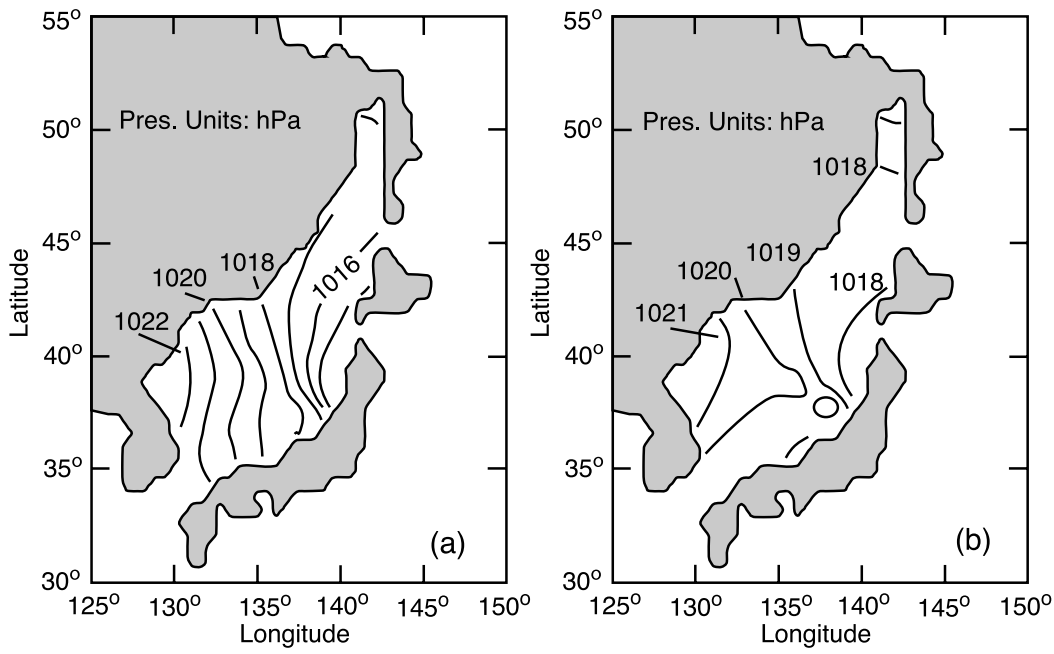

Figure 21. Average spatial structure of the sea level pressure (a) during VCSAO events and (b) during non-VCSAO event periods. 

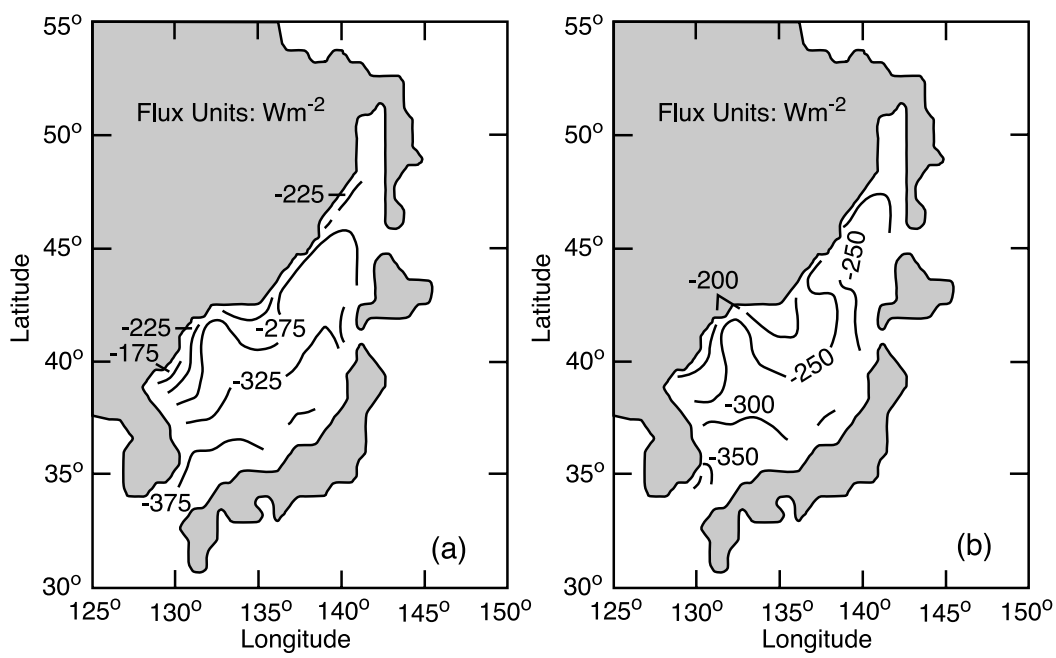

Figure 22. Average spatial structure of the net surface heat flux (a) during VCSAO events and (b) during non-VCSAO event periods.

from 5 to 19. The pattern in the duration of events (Table $3 b$ ) follows that in the frequency of events. It is interesting to note that the 1997/1998 El Niño was not associated with anomalous cold air event activity. In any event, the frequency and duration of VCSAO events during the 1999/ 2000 winter field program were both near average.

[57] Using this VCSAO event definition, we next created a composite event for the 1991-2002 period. For comparison, the composite of conditions without VCSAO events for the December-February period was also created. For the latter, November and March were left out of the analysis since almost all of the VCSAO events that occurred during November and March did so within 7 days of the end of November or the start of March so that including the entire month would bias the winter composite.

[58] The VCSAO composite air temperature is nearly $2^{\circ} \mathrm{C}$ colder, but has the same spatial pattern as for the non-event composite (Figure 20). However, the VCSAO composite sea level pressure isobars are close and oriented northsouth, which is quite different than the non-event composite (Figure 21). Instead, the latter has a more diffuse isobar pattern with a weak low in the southern Japan Sea. Thus the VCSAO composite sea level pressure is consistent with strong northerly flow caused by southward extension of the Siberian High with colder air pushing across the Japan/East Sea.

[59] The VCSAO composite net heat flux is $-325 \mathrm{~W} \mathrm{~m}^{-2}$ in the center of the Japan Sea, with the greatest values exceeding $-375 \mathrm{~W} \mathrm{~m}^{-2}$ in the southwest end of the Japan Sea over the warm Kuroshio Current extension (Figure 22). Along the Russian coast, increased heat loss occurs in the lee of the Vladivostok gap. The non-event composite has a similar net heat flux pattern but with weaker loss, i.e., $-250 \mathrm{~W} \mathrm{~m}^{-2}$ in the center of the sea and $-350 \mathrm{~W} \mathrm{~m}^{-2}$ in the southwest end. Similar patterns occur for the latent and sensible heat fluxes (not shown). The difference
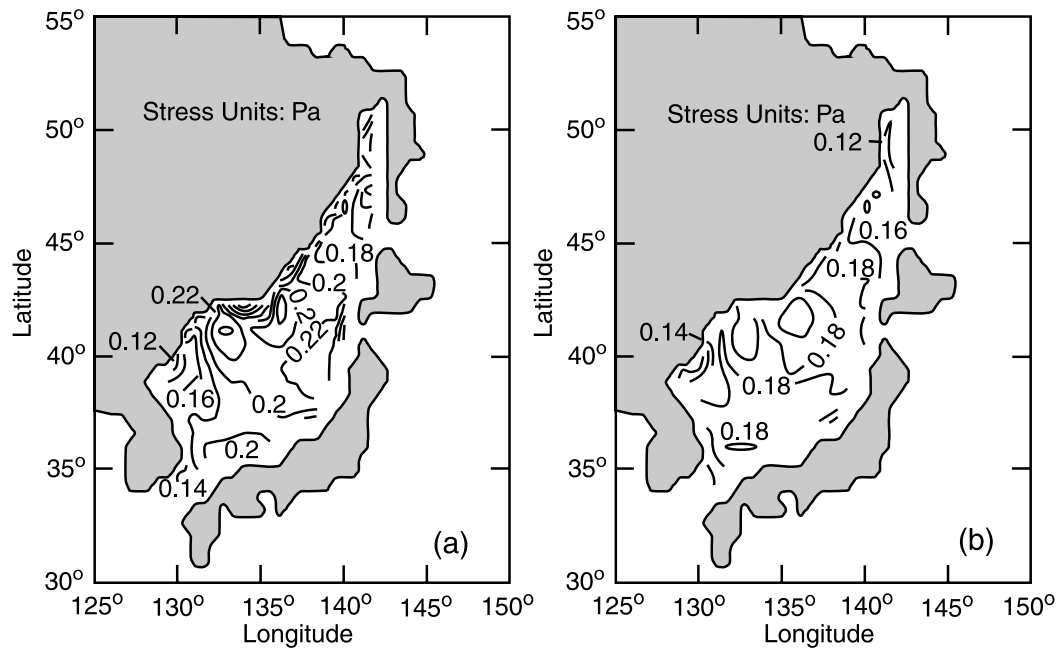

Figure 23. Average spatial structure of the wind stress magnitude (a) during VCSAO events and (b) during non-VCSAO event periods. 

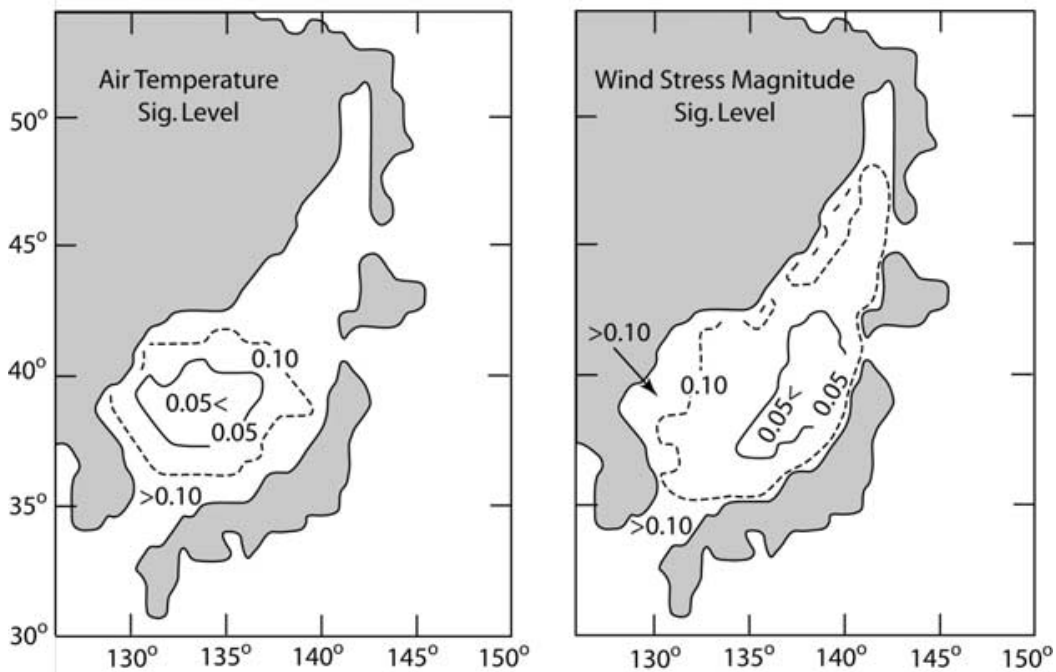

Figure 24. Statistical significance of the air temperature composite (Figure 20) and wind stress magnitude (Figure 23) during VCSAO events compared to non-VCSAO event periods. Contours are for 0.05 (solid line) and 0.10 (dashed line) significance level. These composites are very significant in the center of the Japan Sea.

between the VCSAO event and non-event composites are less distinct for the shortwave and long-wave radiation heat fluxes (not shown). In summary, the heat loss by the Japan Sea is about $18 \%$ greater for the "average" (composite) VCSAO event. As a result, $43 \%$ of the winter net heat loss occurs during VCSAO events.

[60] The composite sea surface wind stress magnitude for the VCASO events and non-event periods have similar patterns, but the wind stress magnitude during the average VCSAO event is about $0.20 \mathrm{~Pa}, 20 \%$ greater than the non-event period (Figure 23). In both VCSAO event and non-event composites, a wind stress maximum extends southward from the Vladivostok gap.

[61] The statistical significance of the above composites for each variable is now considered. Bootstrap resampling [Efron and Gong, 1983] was used in a similar manner as Gershunov [1998] to build up distributions of noise for each grid point based upon the 1991-2002 ECMWF reanalysis. The procedure was done 500 times to compute the statistical significance at 0.05 and 0.10 . The results are presented in Figure 24 in the following format. The chance that the composite value is the same as the non-event is less than 0.05 in the area encircled by the 0.05 contour in the central portion of the Japan Sea, while the chance that the composite value is the same as the non-event is greater than 0.10 for the area outside of the 0.10 contour which includes the outer edges of the Japan Sea.

[62] The air temperature composite is significant to better than 0.10 for the central portion of the Japan Sea with the best values in the very center near $40^{\circ} \mathrm{N}, 134^{\circ} \mathrm{W}$. The wind stress magnitude composite is also most significant in the center of the Japan Sea, while 0.10 or better covers almost all of the sea but the outer edge. An interpretation of this is that the greatest signal of the Very Cold Siberian Air Outbreak is located in the center of the Japan Sea and away from land. No doubt, the ECMWF model has greater difficulty in simulating the greater variations associated with land than sea.

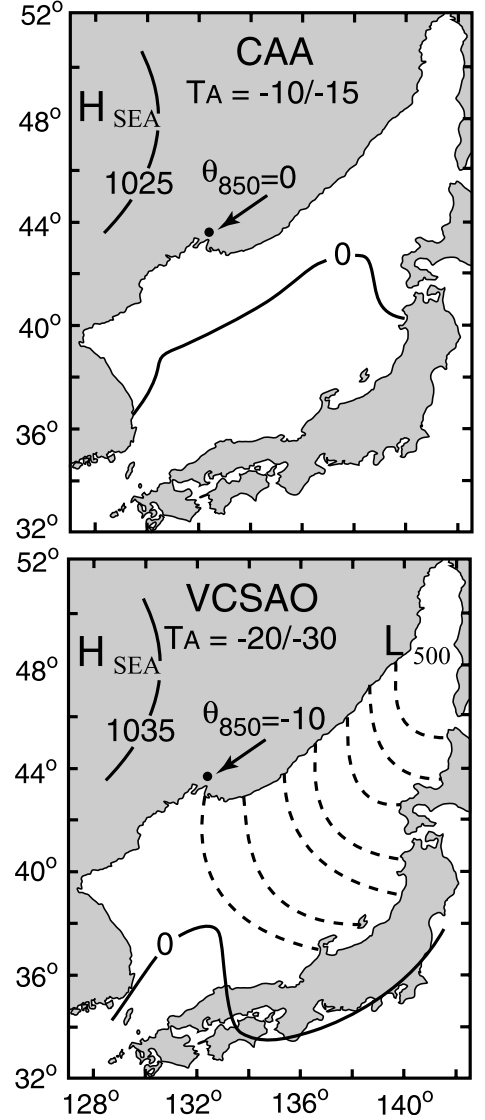

Figure 25. Schematic model showing differences between Cold Asian Air (CAA) and Very Cold Siberian Air Outbreak (VCSAO) conditions. H $\mathrm{H}_{\mathrm{SEA}}$, sea level Siberian high pressure; $\mathrm{L}_{500}, 500-\mathrm{hPa}$ low pressure; line with (top) 1025 and (bottom) 1035 sea level pressure isobar; $\mathrm{T}_{\mathrm{A}}$, Siberian surface air temperature; line with 0 , surface-air $0^{\circ} \mathrm{C}$ isotherm; $\theta_{850}$, Vladivostok 850 -hPa potential temperature; dashed lines, location and orientation of sheet clouds. 
Table 4. January 2000 Characteristics $^{\mathrm{a}}$

\begin{tabular}{|c|c|c|c|c|c|c|c|c|}
\hline Day & VCSAO & $\begin{array}{l}0^{\circ} \mathrm{C} \text { Air } \\
\text { Temperature } \\
\text { at } 135^{\circ} \mathrm{E}\end{array}$ & $\begin{array}{c}0^{\circ} \mathrm{C} \text { Air } \\
\text { Temperature } \\
\text { at } 137.5^{\circ} \mathrm{E}\end{array}$ & $\begin{array}{l}\text { Buoy Air } \\
\text { Temp, }{ }^{\circ} \mathrm{C}\end{array}$ & $\begin{array}{l}\text { Buoy Wind Dir, } \\
\text { deg/Spd, } \mathrm{m} \mathrm{s}^{-1}\end{array}$ & $\begin{array}{l}\text { Vlad Pot } \\
\text { Temp, }{ }^{\circ} \mathrm{C}\end{array}$ & $\begin{array}{c}\text { Vlad } 850-1000 \\
\text { Pot Temp, }{ }^{\circ} \mathrm{C} \\
\end{array}$ & $\begin{array}{c}\text { Sheet or } \\
\text { Roll Cloud }\end{array}$ \\
\hline \multicolumn{9}{|c|}{ January 2000} \\
\hline 1 & & $40.6^{\circ} \mathrm{N}$ & $40.9^{\circ} \mathrm{N}$ & 4.6 & $020^{\circ} / 7.7$ & -2.2 & 2.1 & $40 \% \mathrm{~A}, \mathrm{~F}$ \\
\hline 2 & & $42.2^{\circ} \mathrm{N}$ & $43.6^{\circ} \mathrm{N}$ & 6.8 & $110^{\circ} / 6.2$ & 3.0 & 2.0 & $\mathrm{~N}$ \\
\hline 3 & & $42.6^{\circ} \mathrm{N}$ & $44.5^{\circ} \mathrm{N}$ & 6.9 & $300^{\circ} / 15.9$ & 1.6 & 2.5 & $10 \%$ \\
\hline 4 & & $42.5^{\circ} \mathrm{N}$ & $44.3^{\circ} \mathrm{N}$ & 5.0 & $310^{\circ} / 9.3$ & 0.1 & 2.3 & $10 \%$ \\
\hline 5 & & $42.6^{\circ} \mathrm{N}$ & $44.3^{\circ} \mathrm{N}$ & 7.0 & $090 \% 6.7$ & 1.6 & 1.7 & - \\
\hline 6 & & $43.7^{\circ} \mathrm{N}$ & $45.0^{\circ} \mathrm{N}$ & 13.2 & $170^{\circ} / 11.8$ & 2.8 & 2.5 & $\mathrm{~N}$ \\
\hline 7 & & $39.6^{\circ} \mathrm{N}$ & $41.5^{\circ} \mathrm{N}$ & 1.6 & $330 \% / 16.5$ & -16.0 & 1.2 & $20 \% \mathrm{SW}$ \\
\hline 8 & & $39.6^{\circ} \mathrm{N}$ & $40.7^{\circ} \mathrm{N}$ & 4.3 & $270^{\circ} / 12.9$ & - & - & $20 \% \mathrm{~T}$ \\
\hline 9 & & $41.4^{\circ} \mathrm{N}$ & $42.6^{\circ} \mathrm{N}$ & 6.3 & $340^{\circ} / 1.5$ & -2.2 & 1.8 & $\mathrm{~N}$ \\
\hline 10 & & $40.5^{\circ} \mathrm{N}$ & $42.2^{\circ} \mathrm{N}$ & 5.8 & $350^{\circ} / 7.5$ & -4.3 & 3.1 & $15 \% \mathrm{SW}$ \\
\hline 11 & & $39.3^{\circ} \mathrm{N}$ & $39.7^{\circ} \mathrm{N}$ & 2.6 & $320^{\circ} / 10.3$ & -6.6 & 1.8 & $\mathrm{~N}$ \\
\hline 12 & & $40.4^{\circ} \mathrm{N}$ & $41.7^{\circ} \mathrm{N}$ & 3.8 & $080^{\circ} / 7.7$ & -1.0 & 2.2 & $\mathrm{~N}(1 / 2)$ \\
\hline 13 & & $42.3^{\circ} \mathrm{N}$ & $43.8^{\circ} \mathrm{N}$ & 9.9 & $080^{\circ} / 8.7$ & -0.6 & 2.7 & $\mathrm{~N}$ \\
\hline 14 & & $40.4^{\circ} \mathrm{N}$ & $42.5^{\circ} \mathrm{N}$ & 6.4 & $010^{\circ} / 11.3$ & -0.1 & 1.3 & $\mathrm{~N}$ \\
\hline 15 & & $41.4^{\circ} \mathrm{N}$ & $42.8^{\circ} \mathrm{N}$ & 4.3 & $360^{\circ} / 6.2$ & 1.4 & 1.4 & $\mathrm{~N}$ \\
\hline 16 & & $41.4^{\circ} \mathrm{N}$ & $43.3^{\circ} \mathrm{N}$ & 6.4 & $040^{\circ} / 4.6$ & 0.0 & 2.1 & $\mathrm{~N}$ \\
\hline 17 & & $39.6^{\circ} \mathrm{N}$ & $40.5^{\circ} \mathrm{N}$ & 4.5 & $030^{\circ} / 9.3$ & -3.5 & 1.7 & $\mathrm{~N}$ \\
\hline 18 & & $39.6^{\circ} \mathrm{N}$ & $41.3^{\circ} \mathrm{N}$ & 2.9 & $020^{\circ} / 5.7$ & -4.7 & 1.6 & $\mathrm{~N}$ \\
\hline 19 & & $40.4^{\circ} \mathrm{N}$ & $41.7^{\circ} \mathrm{N}$ & 6.7 & $190^{\circ} / 4.6$ & -6.4 & 1.3 & $10 \% \mathrm{SW}, \mathrm{NE}$ \\
\hline 20 & M & $38.7^{\circ} \mathrm{N}$ & $42.2^{\circ} \mathrm{N}$ & 1.8 & $020^{\circ} / 11.3$ & -17.5 & 1.3 & $40 \%$ \\
\hline 21 & $\mathrm{Y}$ & $38.0^{\circ} \mathrm{N}$ & $38.8^{\circ} \mathrm{N}$ & -1.7 & $320 \% 15.4$ & -10.4 & 1.3 & $80 \% \mathrm{~A}$ \\
\hline 22 & & $40.9^{\circ} \mathrm{N}$ & $40.6^{\circ} \mathrm{N}$ & 1.2 & $010^{\circ} / 3.6$ & - & - & $10 \% \mathrm{SE}, \mathrm{F}$ \\
\hline 23 & & $40.7^{\circ} \mathrm{N}$ & $41.5^{\circ} \mathrm{N}$ & 6.7 & $350^{\circ} / 3.1$ & -1.6 & 2.6 & $\mathrm{~N}$ \\
\hline 24 & M & $39.2^{\circ} \mathrm{N}$ & $39.7^{\circ} \mathrm{N}$ & 5.7 & $040 \% 6.2$ & -8.5 & 1.1 & $70 \% \mathrm{~A}$ \\
\hline 25 & $\mathrm{Y}$ & $37.4^{\circ} \mathrm{N}$ & $33.7^{\circ} \mathrm{N}$ & -2.7 & $010^{\circ} / 12.3$ & -16.0 & 1.0 & $80 \%$ A (VN 42$)$ \\
\hline 26 & $\mathrm{Y}$ & $38.2^{\circ} \mathrm{N}$ & $34.2^{\circ} \mathrm{N}$ & -2.6 & $010^{\circ} / 4.1$ & -14.6 & 1.3 & $90 \% \mathrm{~A}$ \\
\hline 27 & & $38.7^{\circ} \mathrm{N}$ & $34.6^{\circ} \mathrm{N}$ & -0.9 & $340^{\circ} / 11.8$ & 0.1 & 1.8 & $\mathrm{~N}$ \\
\hline 28 & & $41.8^{\circ} \mathrm{N}$ & $42.5^{\circ} \mathrm{N}$ & 4.9 & $340^{\circ} / 7.2$ & 5.1 & 2.4 & $\mathrm{~N}$ \\
\hline 29 & & $42.8^{\circ} \mathrm{N}$ & $44.3^{\circ} \mathrm{N}$ & 7.3 & $230^{\circ} / 6.7$ & 3.0 & 4.1 & $\mathrm{~N}$ \\
\hline 30 & & $41.3^{\circ} \mathrm{N}$ & $43.2^{\circ} \mathrm{N}$ & 6.2 & $320^{\circ} / 10.3$ & -7.6 & 2.5 & - \\
\hline 31 & & $38.4^{\circ} \mathrm{N}$ & $38.5^{\circ} \mathrm{N}$ & 9.5 & $310^{\circ} / 2.6$ & -8.5 & 1.7 & - \\
\hline Mean & & $40.5^{\circ} \mathrm{N}$ & $41.3^{\circ} \mathrm{N}$ & 4.7 & 8.4 & -3.9 & 1.9 & \\
\hline Std. Deviation & & $1.6^{\circ} \mathrm{N}$ & $2.9^{\circ}$ & 3.6 & 3.9 & 6.3 & 0.7 & \\
\hline \multicolumn{9}{|c|}{ February 2000} \\
\hline 1 & & $41.2^{\circ} \mathrm{N}$ & $42.6^{\circ} \mathrm{N}$ & 1.7 & $350^{\circ} / 7.2$ & +6.6 & 19.2 & $\mathrm{~N}, \mathrm{p}$ \\
\hline 2 & & $42.1^{\circ} \mathrm{N}$ & $43.0^{\circ} \mathrm{N}$ & 5.1 & $330^{\circ} / 8.2$ & +5.1 & 16.8 & $20 \% \mathrm{~F}$ east side \\
\hline 3 & & $41.9^{\circ} \mathrm{N}$ & $43.6^{\circ} \mathrm{N}$ & 5.7 & $310^{\circ} / 3.1$ & +0.5 & 11.0 & $\mathrm{~N}$ \\
\hline 4 & & $41.1^{\circ} \mathrm{N}$ & $42.6^{\circ} \mathrm{N}$ & 2.6 & $350^{\circ} / 13.4$ & +3.6 & 13.8 & $20 \% \mathrm{~F}, \mathrm{SE}$ \\
\hline 5 & & $41.9^{\circ} \mathrm{N}$ & $42.5^{\circ} \mathrm{N}$ & 4.2 & $050^{\circ} / 1.0$ & +1.5 & 11.2 & $\mathrm{~N}$ \\
\hline 6 & & $42.0^{\circ} \mathrm{N}$ & $44.0^{\circ} \mathrm{N}$ & 8.0 & $180^{\circ} / 8.7$ & - & - & $\mathrm{N}$ \\
\hline 7 & & $40.1^{\circ} \mathrm{N}$ & $43.2^{\circ} \mathrm{N}$ & 3.1 & $320^{\circ} / 11.8$ & -3.5 & 9.5 & $5 \% \mathrm{~F}, \mathrm{SE}$ \\
\hline 8 & & $40.4^{\circ} \mathrm{N}$ & $42.8^{\circ} \mathrm{N}$ & 3.8 & $240^{\circ} / 17.5$ & -7.1 & 7.5 & $10 \% \mathrm{SE}$ \\
\hline 9 & $\mathrm{Y}$ & $38.0^{\circ} \mathrm{N}$ & $39.2^{\circ} \mathrm{N}$ & -0.8 & $360 \% / 12.9$ & -6.9 & 9.7 & $80 \% \mathrm{~A}$ \\
\hline 10 & & $39.6^{\circ} \mathrm{N}$ & $40.0^{\circ} \mathrm{N}$ & 3.2 & $320^{\circ} / 7.7$ & -4.1 & 7.5 & $40 \% \mathrm{E}$ \\
\hline 11 & & $41.0^{\circ} \mathrm{N}$ & $41.6^{\circ} \mathrm{N}$ & 6.1 & $320^{\circ} / 7.2$ & - & - & $10 \%$ SWF \\
\hline 12 & & $41.2^{\circ} \mathrm{N}$ & $41.0^{\circ} \mathrm{N}$ & 6.8 & $250^{\circ} / 5.1$ & -4.8 & 0.4 & $\mathrm{~N}$ \\
\hline 13 & & $39.8^{\circ} \mathrm{N}$ & $40.0^{\circ} \mathrm{N}$ & 2.5 & $050^{\circ} / 3.6$ & -4.3 & 9.0 & $30 \% \mathrm{EF}$ \\
\hline 14 & & $39.4^{\circ} \mathrm{N}$ & $40.9^{\circ} \mathrm{N}$ & 6.0 & $290^{\circ} / 4.1$ & -7.6 & 7.5 & $10 \% \mathrm{NE}, \mathrm{F}$ \\
\hline 15 & $\mathrm{Y}$ & $37.7^{\circ} \mathrm{N}$ & $34.9^{\circ} \mathrm{N}$ & 0.1 & $030^{\circ} / 10.8$ & -13.1 & 3.1 & $80 \% \mathrm{~A}, \mathrm{I}$ \\
\hline 16 & $\mathrm{Y}$ & $37.5^{\circ} \mathrm{N}$ & $34.6^{\circ} \mathrm{N}$ & -2.3 & $330 \% / 14.9$ & -11.7 & 5.6 & $80 \% \mathrm{~A}$ \\
\hline 17 & $\mathrm{Y}$ & $38.0^{\circ} \mathrm{N}$ & $34.7^{\circ} \mathrm{N}$ & 0.4 & $330^{\circ} / 8.2$ & -8.1 & 6.9 & $80 \% \mathrm{~A}$ \\
\hline 18 & $\mathrm{Y}$ & $39.5^{\circ} \mathrm{N}$ & $39.8^{\circ} \mathrm{N}$ & 0.4 & $330^{\circ} / 8.2$ & -7.3 & 7.3 & $80 \% \mathrm{~A}$ \\
\hline 19 & & $41.8^{\circ} \mathrm{N}$ & $42.1^{\circ} \mathrm{N}$ & 2.2 & $000^{\circ} / 0.0$ & -3.1 & 8.9 & $5 \%$ \\
\hline 20 & & $38.8^{\circ} \mathrm{N}$ & $39.4^{\circ} \mathrm{N}$ & 4.1 & $020^{\circ} / 10.8$ & - & - & $\mathrm{N}$ \\
\hline 21 & $\mathrm{Y}$ & $38.3^{\circ} \mathrm{N}$ & $39.0^{\circ} \mathrm{N}$ & 0.5 & $330 \% 12.3$ & -9.2 & 4.8 & $80 \% \mathrm{~A}, \mathrm{I}$ \\
\hline 22 & $\mathrm{Y}$ & $38.6^{\circ} \mathrm{N}$ & $38.0^{\circ} \mathrm{N}$ & 0.2 & $340^{\circ} / 10.3$ & -10.6 & 4.0 & $80 \% \mathrm{~A}$ \\
\hline 23 & & $39.5^{\circ} \mathrm{N}$ & $40.2^{\circ} \mathrm{N}$ & 1.6 & $120 \% 6.2$ & -3.3 & 5.3 & $20 \%$ NA \\
\hline 24 & $\mathrm{Y}$ & $37.4^{\circ} \mathrm{N}$ & $34.5^{\circ} \mathrm{N}$ & -1.1 & $040^{\circ} / 13.9$ & -10.8 & 2.9 & $90 \% \mathrm{~A}$ \\
\hline 25 & $\mathrm{Y}$ & $39.0^{\circ} \mathrm{N}$ & $39.0^{\circ} \mathrm{N}$ & -0.3 & $360 \% 6.7$ & - & - & $30 \% \mathrm{NE}, \mathrm{A}, \mathrm{F}$ \\
\hline 26 & & $40.7^{\circ} \mathrm{N}$ & $41.0^{\circ} \mathrm{N}$ & 2.3 & $110^{\circ} / 9.3$ & -0.7 & 9.5 & $\mathrm{~N}$ \\
\hline 27 & & $38.9^{\circ} \mathrm{N}$ & $41.9^{\circ} \mathrm{N}$ & 0.5 & $330^{\circ} / 7.7$ & -5.4 & 2.8 & - \\
\hline 28 & $\mathrm{Y}$ & $37.6^{\circ} \mathrm{N}$ & $33.9^{\circ} \mathrm{N}$ & -0.8 & $070^{\circ} / 7.2$ & -9.4 & 4.6 & $10 \% \mathrm{I}$ \\
\hline 29 & $\mathrm{Y}$ & $39.6^{\circ} \mathrm{N}$ & $38.2^{\circ} \mathrm{N}$ & -0.7 & $340^{\circ} / 10.8$ & -8.3 & 5.4 & $70 \% \mathrm{~A}$ \\
\hline Mean & & $39.7^{\circ} \mathrm{N}$ & $39.9^{\circ} \mathrm{N}$ & 2.2 & 8.6 & -4.9 & 7.8 & \\
\hline Std. Deviation & & $1.5^{\circ}$ & $3.0^{\circ}$ & 2.7 & 4.1 & 5.3 & 4.4 & \\
\hline
\end{tabular}




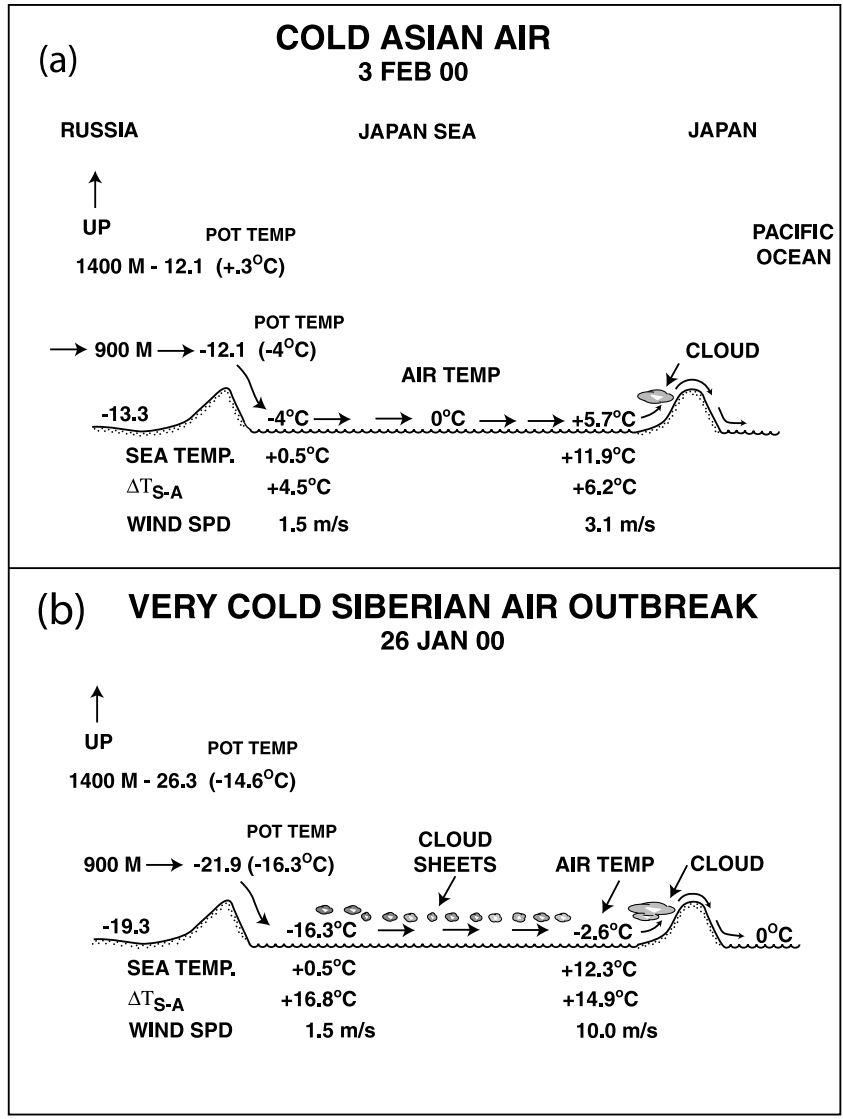

Figure 26. A schematic on the role of Russian coastal mountains in lee-side warming during (a) cold Asian air and (b) very cold Siberian air moving over the Japan Sea.

[63] The sea surface pressure and total heat flux composites are not shown, as their significance value magnitudes do not drop below 0.10 anywhere in the sea. An interpretation of this is that the standard deviation of these variables is large compared to the composite mean, limiting the confidence in the uniqueness of these composites. However, these composites are consistent with our experience and suggest the approximate structure that probably would be confirmed with a longer data record.

\section{Discussion}

[64] We now consider why the air temperatures on the Russian coast away from Vladivostok are relatively warm during the dominantly occurring CAA conditions (Figure 25). The strong surface inversion capped by a deep isothermal layer (measured at Vladivostok) and the weak northerly winds (Table 4) show that the coldest inland surface air is blocked by the Russian coastal mountains.
The reduced drag over the sea in the lee causes acceleration and thus surface divergence, so that air from above the coastal ridge is pulled down in the lee of the coastal mountains, warming the coastal air to a temperature only $5^{\circ}-10^{\circ} \mathrm{C}$ cooler than that of the sea surface (Figure 26).

[65] In contrast, during VCSAO events, both the surface and $1.5-\mathrm{km}$ air temperatures over the Russian continental interior decrease to $-20^{\circ} \mathrm{C}$ and $-30^{\circ} \mathrm{C}$, greatly reducing the stability and eliminating the surface inversion (Table 1, Figure 25). The result is that the air, originating from 500- to $1000-\mathrm{m}$ elevation inland, moves over the Russian coastal range, and, although it is adiabatically warmed, it is still much colder than that observed during CAA conditions.

[66] The CAA boundary layer on the Russian coast is convectively mixed with the sea temperature greater than the air [Stull, 1988]. The sea surface temperature also increases downwind, so that there will continue to be an upward heat and moisture flux, and the well-mixed marine boundary layer grows and warms as it moves quickly across the Japan Sea. However, mixing in drier air from above keeps the marine air too dry to form clouds.

[67] Why is it that stratocumulus sheet clouds that occur during VCSAOs do not occur with the more frequent CAA conditions? There seem to be three elements. One is a low, capping inversion that restricts mixing drier air from above which is supported by the dew point depression being zero at buoy 21002 only during several VCSAO events. The second is the factor of 2 greater upward heat fluxes due to greater sea-air temperature differences and faster winds. The third is nearly uniform conditions experienced by the air as it moves across the sea as shown in the satellite images of the uniform cloud field. Somewhat similar conditions have been found in the Labrador Sea [Renfrew and Moore, 1999].

[68] The Japan Sea cloud sheet conditions fit with those experienced elsewhere. It is widely felt that they are caused by Rayleigh-Bénard instability in the presence of vertical shear, inflection point instability, and parallel instability, with the first two the most important [Liu et al., 2004; Atkinson and Zhang, 1996; Etling and Brown, 1993]. There are insufficient observations in this case to statistically distinguish between these possibilities.

\section{Summary}

[69] There are four main synoptic winter weather conditions over the Japan Sea. Most frequently occurring is Cold Asian Air flowing off Russia. Adiabatic descent in the lee of the Russian coastal mountains warms the air mass $10^{\circ}-15^{\circ} \mathrm{C}$, dramatically reducing sea surface sensible heat loss. At the same time, extension of the Siberian High clears the sky, allowing in maximum solar radiation and further decreasing the net sea surface heat loss.

[70] The strongest heat fluxes are during the less frequently occurring Very Cold Siberian Air Outbreak

\footnotetext{
Notes to Table 4:

${ }^{a}$ All values at 0000 UTC. VCSAO, Very Cold Siberian Air Outbreak; Y, yes; M, maybe; $0{ }^{\circ} \mathrm{C}$ at $135^{\circ} \mathrm{E}$ and $0{ }^{\circ} \mathrm{C}$ at $137.5^{\circ} \mathrm{E}$, latitude of $0{ }^{\circ} \mathrm{C}$ surface air temperature isotherm from ECMWF; Buoy Air Temp and Wind Dir/Spd, Buoy 21002 air temperature and wind direction and speed; Vlad Pot Temp and 850 - 1000 Pot Temp, Vladivostok $850 \mathrm{hPa}$ potential temperature and 1000 minus $850 \mathrm{hPa}$ potential temperature; Sheet or Roll Cloud, percent Japan Sea coverage by sheet or roll cloud coverage; N, no roll clouds; NE, in the northeast area of Japan Sea; SE, in the southeast area of Japan Sea; p, problem with image quality; I, intermediate clouds; A, extends from near Russia to Japan; F, fuzzy rolls; T, thin, broken; SW, in southwest area of Japan Sea; (VN 42), view only north of $42^{\circ} \mathrm{N}$.
} 
(VCSAO) events. The air mass flows from a similar direction as the mean, but expansion of the Siberian High causes the air temperature to be much colder and creates a quasi-isothermal layer extending from the surface to above the height of the Russian coastal mountains. The combination of $10^{\circ}-15^{\circ} \mathrm{C}$ colder air, faster winds, and marine sheet clouds results in about twice the net heat flux loss from the sea surface as during the mean condition.

[71] A unique marine boundary layer feature during VCSAO events is the formation of uniform sheet clouds that can cover the entire Japan Sea. This process occurs due to a uniform temperature difference between the air and sea surface as the air mass moves over the sea, which is maintained by the air temperature increasing at the same rate as the temperature of the water it is moving over. Satellite visual images of uniform sheet clouds extending across the Japan Sea are a testimonial to quasi-uniform boundary layer conditions.

[72] A statistical study was done of VCSAO events over the Japan Sea based upon the ECMWF analysis for 19912002. While an average of 13.5 VCSAO events occurred in the months of November-March, most were in DecemberFebruary. The seasonal number of VCSAO events ranged from 5 to 19; 14 VCSAO events occurred during the 1999/ 2000 winter season, close to the 11-year average, suggesting that our 1999/2000 winter measurements were typical of this season. The composite "average" VCSAO event surface air temperature was $-2^{\circ} \mathrm{C}$ colder over the entire Japan Sea than during the non-event period. The VCSAO composite net heat flux loss was $18 \%$ larger than during the non-event period, with the greatest difference occurring in the center of the sea. The magnitude of the surface wind stress was $0.02 \mathrm{~Pa}$ or about $20 \%$ greater during the average VCSAO event.

[73] The other two basic synoptic events are passing disturbances. One is a weak cyclonic disturbance moving over the southern edge of the Japan Sea that causes a brief VCSAO event in the western edge of the system. The other is a moderate cyclone moving over the northern portion of the Japan Sea that results in much higher air temperatures and small sea surface heat fluxes.

[74] Acknowledgments. Doug Aldan (SIO) took the winter 2000 $\mathrm{R} / \mathrm{V}$ Revelle cruise on short notice, making soundings and processing surface data. Aldan and Jonathan Ware (WHOI) deployed the selfcontained meteorological instrumentation on the Revelle. We want to acknowledge their skill and help in obtaining the best possible shipboard data set, without which this study would not be possible. Ryota Matsumoto (Tokai University) provided the geostationary satellite images. We thank Eugeney Uraevsky (FERHRI) for the Timiryazevsky surface data. We also thank the crews and support staff of the R/V Revelle and R/V Khromov for their help with the shipboard meteorological measurements. Finally, we want to thank John Toole and the reviewers for their patience and help in making this a better paper. Support for this program was provided by the Office of Naval Research through grants N00014-98-1-0345, N00014-99-10205, and N00014-98-1-0210.

\section{References}

Atkinson, B. W., and J. W. Zhang (1996), Mesoscale shallow convection in the atmosphere, Rev. Geophys., 34, 403-431.

Beardsley, R. C., E. P. Dever, S. J. Lentz, and J. P. Dean (1998), Surface heat flux variability over the northern California shelf, J. Geophys. Res., 103(C10), 21,553-21,586.

Boyle, J., and T.-J. Chen (1987), Synoptic aspects of the wintertime East Asian monsoon, in Monsoon Meteorology, edited by C. P. Chang and T. N. Krishnamurti, pp. 125-160, Oxford Univ. Press, New York.
Bradley, E. F., C. W. Fairall, J. E. Hare, and A. A. Grachev (2000), An old and improved bulk algorithm for air-sea fluxes: COARE 2.6 A, paper presented at 14th Symposium on Boundary Layer and Turbulence, Am. Meteorol. Soc., Aspen, Colo.

Crutcher, H. L., and J. M. Meserve (1970), Selected level heights, temperatures and dew points for the Northern Hemisphere, NAVIR 50-1C-52, Nav. Weather Serv. Command, Washington, D. C.

Dashko, N. A., and S. M. Varlamov (1997), Wind regime in coastal area of Japan Sea (in Russian), Bull. Far East. Reg. Hydrometeorol. Res. Inst., $148,61-75$

Dashko, N. A., and S. M. Varlamov (2000), Assessments of the 20th century variability of characteristics and influence on the Japan Sea circulation of the Pacific-Asian atmospheric action centers (in Russian with English abstract), in Hydrometeorological and Ecological Conditions in the Far Eastern Seas: Marine Environmental Impact Assessment, Spec. Issue 3, pp. 10-25, Far-East. Reg. Hydrometeorol. Res. Inst. (FERHRI), Vladivostok, Russia.

Dashko, N. A., S. M. Varlamov, Y. H. Han, and Y.-S. Kim (1997), Wind direction over the Japan Sea (in Russian), Bull. Far East. Reg. Hydrometeorol. Res. Inst., 148, 85-101.

Efron, B., and G. Gong (1983), A leisurely look at the bootstrap, the jackknife, and cross-validation, Am. Stat., 37, 36-48.

Etling, D., and R. A. Brown (1993), Roll vortices in the planetary boundary layer: A review, Boundary Laver Meteorol., 65, 215-248.

European Centre for Medium-Range Weather Forecasts (1995), The description of the ECMWF/WCRP level III-A global atmospheric data archive, 23 pp., Reading, England.

Fairall, C. W., E. F. Bradley, J. E. Hare, A. A. Grachev, and J. B. Edson (2003), Bulk parameterization of air-sea fluxes: Updates and verification for the COARE algorithm, J. Clim., 16, 571-590.

Fett, R. W. (1979), Navy tactical applications guide, vol. 2, Environmental phenomena and effects, NAVENVPREDRSCHFAC Tech. Rep. 77-04, 161 pp., Naval Air Syst. Command, Dep. of the Navy, Washington, D. C.

Gershunov, A. (1998), ENSO influence on intraseasonal extreme rainfall and temperature frequencies in the contiguous United States: Implications for long-range predictability, J. Clim., 11, 3192-3204.

Hirose, N., C.-H. Kim, and J.-H. Yoon (1996), Heat budget in the Japan Sea, J. Oceanogr., 52, 553-574.

Hosom, D. S., and R. A. Weller (2001), A climate quality data collection system for volunteer observing ships, paper presented at Fifth Symposium on Integrated Observing Systems, Am. Meteorol. Soc., Albuquerque, N. M.

House, R. A. (1993), Cloud Dynamics, 573 pp., Academic, San Diego, Calif. Hozumi, K., and C. Magono (1984), The cloud structure of convergent cloud bands over the Japan Sea in winter monsoon period, J. Meteorol. Soc. Jpn., 62, 522-533.

Kato, K., and T. Asai (1983), Seasonal variations of heat budgets in both the atmosphere and the sea in the Japan Sea area, J. Meteorol. Soc. Jpn., $61,222-237$.

Kawamura, H., and P. Wu (1998), Formation mechanism of Japan Sea Proper Water in the flux center off Vladivostok, J. Geophys. Res., 103, $21,611-21,622$.

Liu, A. Q., G. W. K. Moore, K. Tsuboki, and I. A. Renfrew (2004), A highresolution simulation of convective roll clouds during a cold-air outbreak, Geophys. Res. Lett., 31(3), L03101, doi:10.1029/2003GL018530.

Manabe, S. (1957), On the modification of air-mass over the Japan Sea when the outburst of cold air predominates, J. Meteorol. Soc. Jpn., Ser. II, $35,311-326$.

Manabe, S. (1958), On the estimation of energy exchange between the Japan Sea and the atmosphere during winter based upon the energy budget of both atmosphere and sea, J. Meteorol. Soc. Jpn., Ser. II, 36, $123-134$.

Martin, S., E. Munoz, and R. Drucker (1992), The effect of severe storms on the ice cover of the northern Tatarskiy Strait, J. Geophys. Res., 97, $17,753-17,764$

Moore, G. W. K., and I. A. Renfrew (2002), An assessment of the surface turbulent heat fluxes from the NCEP-NCAR Reanalysis over the Western Boundary Currents, J. Clim., 15, 2020-2037.

Na, J.-Y., J.-W. Seo, and S.-K. Han (1992), Monthly-mean sea surface winds over the adjacent seas of the Korea Peninsula(r), J. Oceanol. Soc. Korea, 27, 1-10.

Na, J., J. Seo, and H.-J. Lie (1999), Annual and seasonal variations of the sea surface heat fluxes in the East Asian marginal seas, J. Oceanogr., 55, 257-270.

Nagata, M., M. Ikawa, S. Yoshizumi, and T. Yoshida (1986), On the formation of a convergent cloud band over the Japan Sea in winter: Numerical experiments, J. Meteorol. Soc. Jpn., 64, 841-855.

Pawlowicz, R., R. Beardsley, S. Lentz, E. Dever, and A. Anis (2001), Software simplifies air-sea data estimates, Eos Trans. AGU, 82(1), 2. 
Ramage, C. S. (1971), Monsoon Meteorology, Academic, 296 pp., San Diego, Calif.

Renfrew, I. A., and G. W. K. Moore (1999), An extreme cold-air outbreak over the Labrador Sea: Roll vortices and air-sea interaction, Mon. Weather Rev., 127, 2379-2394.

Renfrew, I. A., G. W. K. Moore, P. S. Guest, and K. Bumke (2002), A comparison of surface layer and surface turbulent flux observations over the Labrador Sea with ECMWF Analyses and NCEP Reanalyses, J. Phys. Oceanogr., 32, 383-400.

Stull, R. B. (1988), An Introduction to Boundary Layer Meteorology, 666 pp., Kluwer Acad., Norwell, Mass.

Wallace, J. M. (1983), The climatological mean stationary waves: Observational evidence, in Large-Scale Dynamical Processes in the Atmosphere, edited by B. Hoskins and R. Pearce, pp. 27-54, Academic, San Diego, Calif.

Whittaker, L. M., and L. H. Horn (1982), Atlas of Northern Hemisphere extratropical cyclone activity, 1958-1977, report, Dep. of Meteorol., Univ. of Wisc., Madison.

Yakunin, L. P. (1999), Ice drift and thickness in the Sea of Japan, paper presented by Fourth CREAMS Workshop, February 1996, Far-East. Reg. Hydrometeorol. Res. Inst., Vladivostok, Russia.
Yeh, F. W. C., and G. T. J. Chen (1984), Some aspects of front climatology over southern part of China and the adjacent oceans in winter half year (in Chinese with English abstract), Q. J. Meteorol., 101, 9-20.

R. C. Beardsley and R. Limeburner, Department of Physical Oceanography, Woods Hole Oceanographic Institution, Woods Hole, MA 02543, USA.

K. Cho, Research and Information Center, Tokai University, 2-28-4, Tomigaya, Shibuya-ku, Tokyo 151, Japan.

N. A. Dashko and S. M. Varlamov, Dynamics Simulation Research Center, Research Institute for Applied Mechanics, Kyushu University, 6-1 Kasuga koen, Kasuga 816-8580, Japan.

C. E. Dorman, Center for Coastal Studies, Scripps Institution of Oceanography, University of California, San Diego, 9500 Gilman Drive, La Jolla, CA 92093-0209, USA. (cdorman@ucsd.edu)

C. A. Friehe and D. Kheilf, Department of Mechanical and Aerospace Engineering, University of California, Irvine, Irvine, CA 92097-3975, USA. 